\title{
The Norman Site: Descriptions
}

Lois E. Albert

Unknown

Follow this and additional works at: https://scholarworks.sfasu.edu/ita

Part of the American Material Culture Commons, Archaeological Anthropology Commons, Environmental Studies Commons, Other American Studies Commons, Other Arts and Humanities Commons, Other History of Art, Architecture, and Archaeology Commons, and the United States History Commons

Tell us how this article helped you.

This Article is brought to you for free and open access by the Center for Regional Heritage Research at SFA ScholarWorks. It has been accepted for inclusion in Index of Texas Archaeology: Open Access Gray Literature from the Lone Star State by an authorized editor of SFA ScholarWorks. For more information, please contact cdsscholarworks@sfasu.edu. 


\section{The Norman Site: Descriptions}

Creative Commons License

(c) (i) (8)

This work is licensed under a Creative Commons Attribution-NonCommercial 4.0 International License 


\title{
THE NORMAN SITE: DESCRIPTIONS
}

\author{
Lois E. Albert
}

\section{ENVIRONMENTAL BACKGROUND}

The Norman site (34WG2) lay on a terrace on the west side of the Neosho (Grand) River in Wagoner County, Oklahoma (Figure 1). Throughout much of its course within Oklahoma, this river flows along the western boundary of the Ozark Uplift. East of the river, the limestones, shales, and sandstones deposited during the Upper Mississippian and Pennsylvanian geological periods form the Boston Mountains and the Springfield Plateau (Figure 2; Huffman 1958:11). Several of these formations contain knappable cherts, often of good quality. West of the river, the Mississippian and Pennsylvanian deposits thin and dip under the surface to form the Prairie Plains Province, characterized by low, east-facing escarpments. Sandstone and shale bedrocks underlie the Prairie-Plains Province (Huffman 1958: 11-12). The streams flowing eastward across these are muddy and sluggish.

Creeks and rivers originating in the Ozarks are clear and spring fed. Fourteen Mile Creek joins the Neosho about four miles south of the Norman site. North of this creek lies the Springfield Plateau whose valley cut $200-300$ feet deep; southward rear the rugged Boston Mountains. Near their western edge, valley bottoms lie $300-500$ feet below the mountain crests (Huffman 1958:12).

Along the rivers and streams, Quaternary period alluvial deposits comprise the floodplain and terraces. Many of these Quaternary deposits, such as those at the Norman site, have been covered by reservoirs such as Fort Gibson. Extensive areas of well defined, alluvial floodplain and terraces would have been present along the Neosho before the reservoir was constructed. These bottomlands would have provided ample space for prehistoric horticulture. Because the reservoir was built before a soil survey of the county had been done, the soil types present at the site were not defined. However, for several miles below the Fort Gibson dam, the mapped soils are Radley silt loam on the floodplain and Mason silt loam on low terraces (Polone 1976:20, 25-26, Sheets $40,46)$. Both soils were formed under hardwood forest with an understory of tall grasses (Polone 1976:20, 25). 


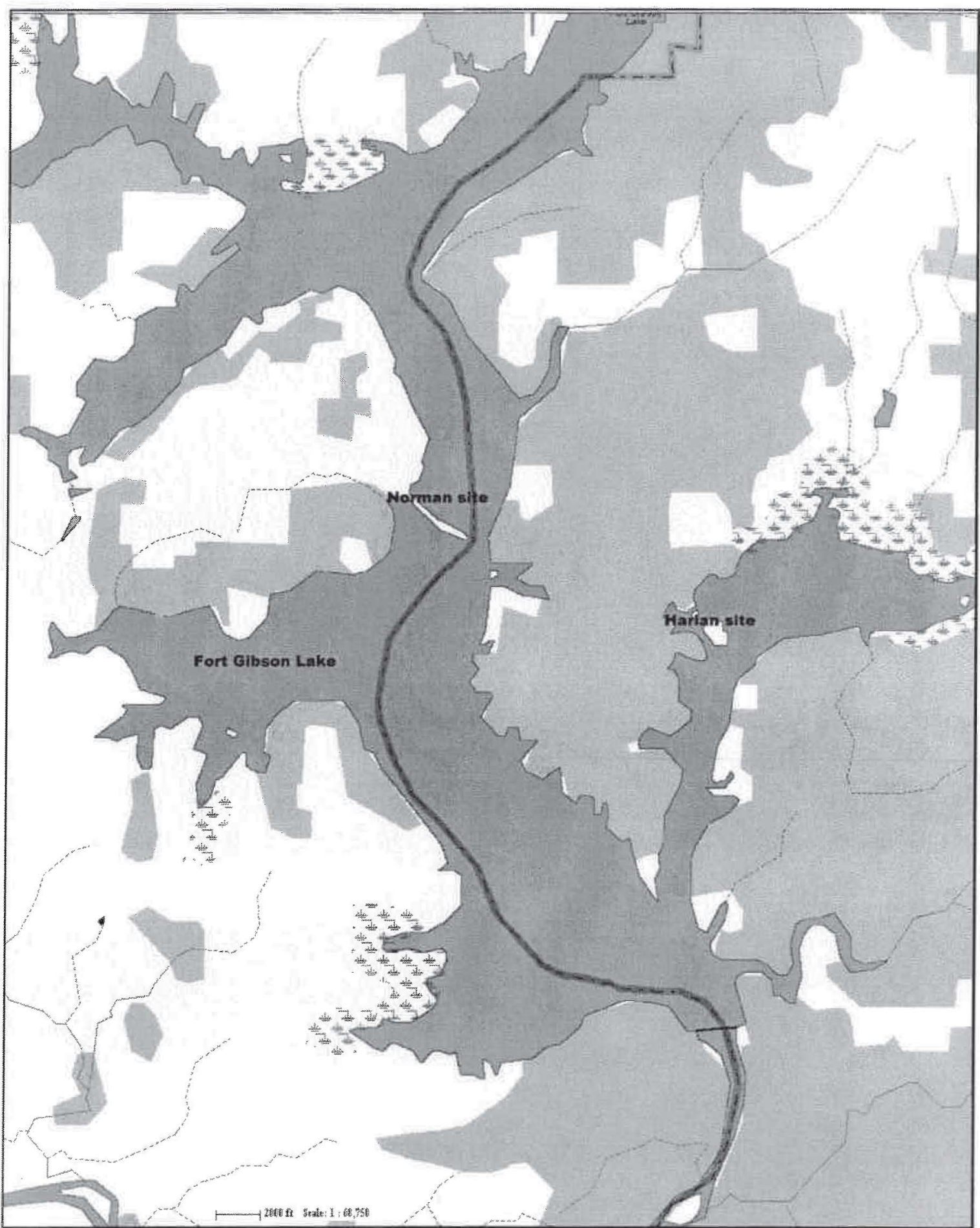

Figure 1. The Fort Gibson Lake area showing the general locations of the Norman site (34WG2) and the Harlan site (34CK6). 


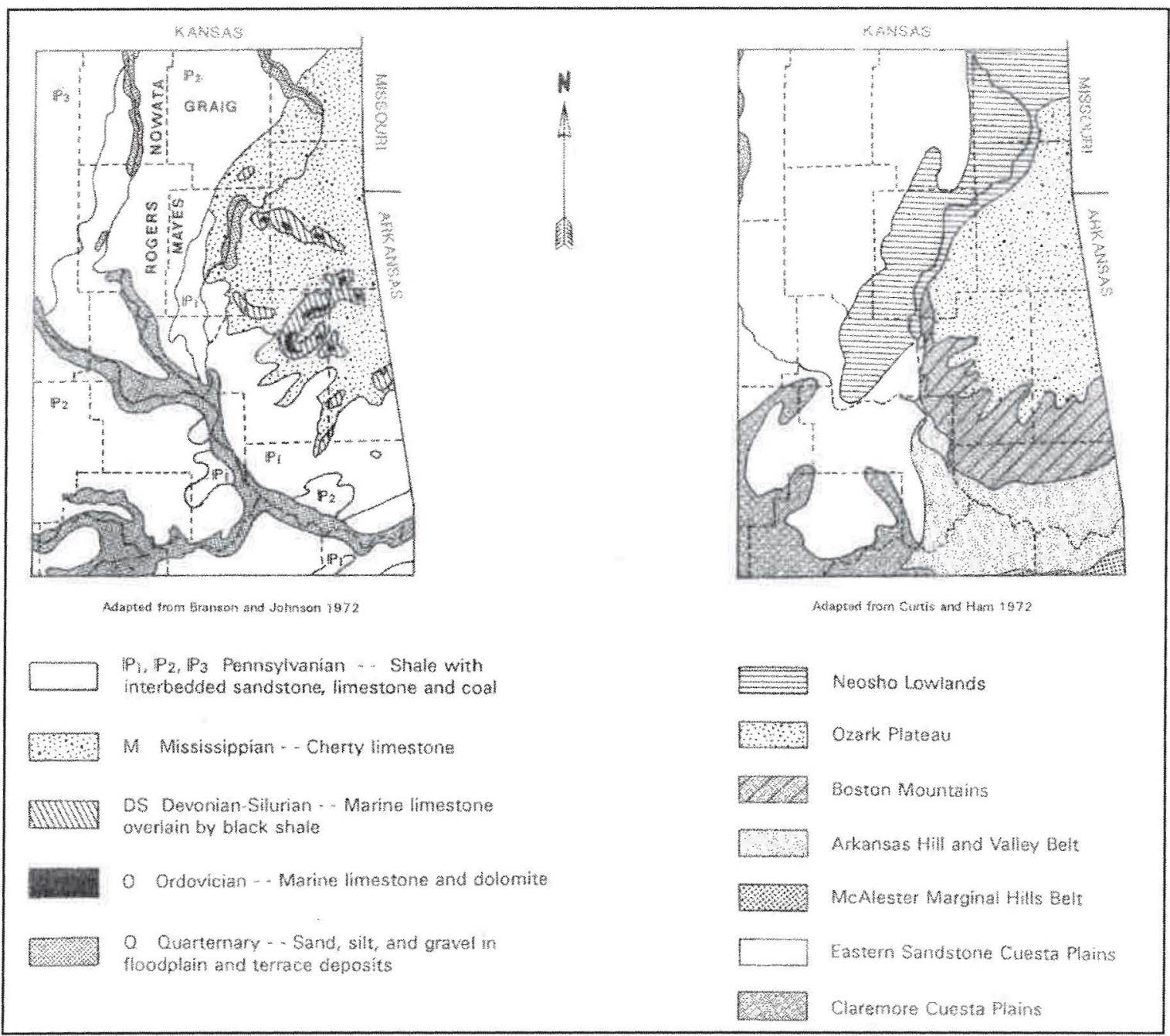

Figure 2. Surface geology and geomorphic provinces in northeastern Oklahoma.

The Neosho River forms the boundary between the oak-hickory forests of the Ozarks and the tall grass prairie to the west (Figure 3). Little (1938), during a vegetation study in adjoining Muskogee County, found four major types of vegetation, controlled largely by physiography. An oak-hickory forest grew on sandstone hills, prairies on shale, maple-oak forest on small areas of limestone, and flood- plain forest along the streams. Cultivation and overgrazing have destroyed much of the original vegetation.

Oklahoma's climate is continental with long, hot summers and short, relatively mild winters. The prevailing winds are from the south during most of the year, although northerly winds are frequent during the winter months (Polone 1976: 


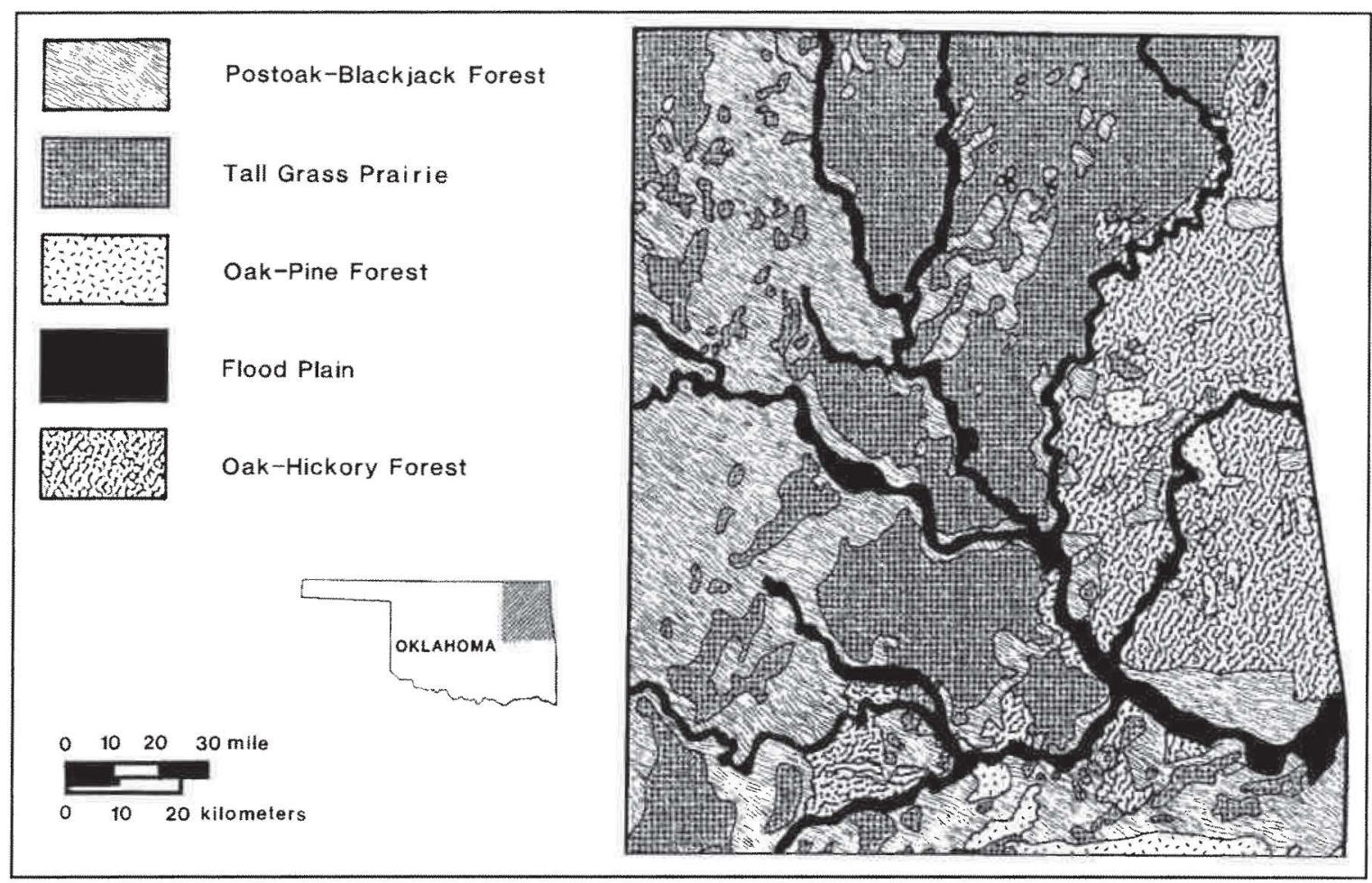

Figure 3. Vegetation types of northeastern Oklahoma (adapted from Duck and Fletcher 1943).

63). At Wagoner, about seven miles from the Norman site, the average annual precipitation for the years 1941-1970 was about 42 inches per year (Polone 1976: 62 ). The mean minimum January temperature was $27^{\circ}$ and the mean maximum was $49^{\circ} \mathrm{F}$ (Curry 1976). For July, the mean minimum was $70^{\circ}$ and mean maximum $95^{\circ} \mathrm{F}$. At Muskogee, there was an average of 216 freeze-free days, with a mean last frost date of March 31 and a mean first frost date of November 1. The region's climate has varied considerably in the past, with the end of the Pleistocene around 12,000 to 10,000 years ago and a warmer period termed the Hypsithermal or Altithermal between 7000 and 5000 years ago (Albert and Wyckoff 1984). However, climatic conditions during the time when mound building began at the Norman site were probably similar to those of today. There are some indications that a drying trend may have been underway by around A.D. 1000 (Albert and Wyckoff 1984:42). This may have contributed to the abandonment of sites such as Harlan and Norman on the western periphery of the Caddoan area after about A.D. 1200. 


\section{SITE DESCRIPTION}

Although the Neosho River valley is narrow through most of its course in Wagoner County, a wide stretch of bottomland, about a half mile east-west and three-quarters north-south formed the setting for the mound center. The generally southward flowing stream was deflected eastward by a steep hillside just north of the Norman site (Finkelstein and Bell 1950:6). The stream then flowed southward again past the site. At this point, the floodplains and terraces rose about 25 feet above the river. A slough lay to the west, with higher terraces rising beyond the opposite bank. East of the river, a high bluff formed a backdrop for the site.

Some information about 1932-33 site conditions has survived in the form of very brief field notes, by J. Joe Finkelstein and Forrest Clements. Some photos from 1928 are in the Western History Collections, University of Oklahoma Library. According to the WPA notes, the Norman site consisted of three large mounds and at least two, probably three and perhaps more, smaller mounds (see Finkelstein, this volume, Figure A). Two of the larger mounds, I and II, were double lobed. The third (Mound III) was a single, conical feature. Structures were documented by the WPA excavations under the mounds, on several mound surfaces, and to the north and south of Mound I. The following descriptions of the 1930 s federal project work through the University of Oklahoma were extracted from notes (Finkelstein 1932, 1934), maps, unpublished reports (Finkelstein 1934/5, 1940a;
Finkelstein and Bell 1950), photographs, and an article in The Oklahoma Prehistorian by J. Joe (Bauxar) Finkelstein (1940c; reprinted in this volume). ${ }^{1}$ Finkelstein annotated the notes in 1949. Additional site information was obtained during 1948 excavations into Mound Ia and Area A by the University of Oklahoma and the River Basin Survey at the Smithsonian Institution. The 1948 work was documented by notes, drawings, photographs, and unpublished reports by Robert E. Bell $(1948 a, b)$ and Joseph Caldwell (1948a,b). These written materials have been curated and stored at the Sam Noble Oklahoma Museum of Natural History (SNOMNH).

1 Little attempt has been made to interpret the stratigraphy. Much more excavation has been done at mound sites and more has been published in the years since the work at the Norman site. Because our techniques and knowledge have improved greatly through this time, we know that the number of stages and substages is greater than those presented here. However, this paper is mainly meant to present the views of the excavators at and near the time of the original work. Additional work is planned for the small portion of Mound I which is still extant (see Vogele, this volume). It is hoped that this new information, which will hopefully be available sometime within the next few years, will be much more useful than an attempt to discern the stratigraphy from the often scanty and confusing documentation from the 1930 s and 1940 s. 


\section{SITE UNIT IVa}

Site Unit IVa was apparently an occupation area with debris extending north and northeast of Mound Ib (see Finkelstein, Figure $\mathrm{A}$, this volume, p. 7). It may have extended as far as 1000 feet; however, only knapping debris was noted on the surface in the northern half of the area (Finkelstein and Bell 1950:9). Debris was found both on the surface and in test trenches dug at several points in the field around the mound (Finkelstein and Bell 1950). The western extent of the debris was limited by swales which might have been borrow pits for the construction of Mound I or possibly an old channel of the Grand River.

\section{MOUND I}

Mound I was the largest of the mounds at the site; it consisted of two conical mounds (Ia and $\mathrm{Ib}$ ) connected by a "sad- dle" (Ic). During the 1930s, the larger mound (Ia; Figure 4) measured 27 feet high and 90 to 150 feet in diameter (this

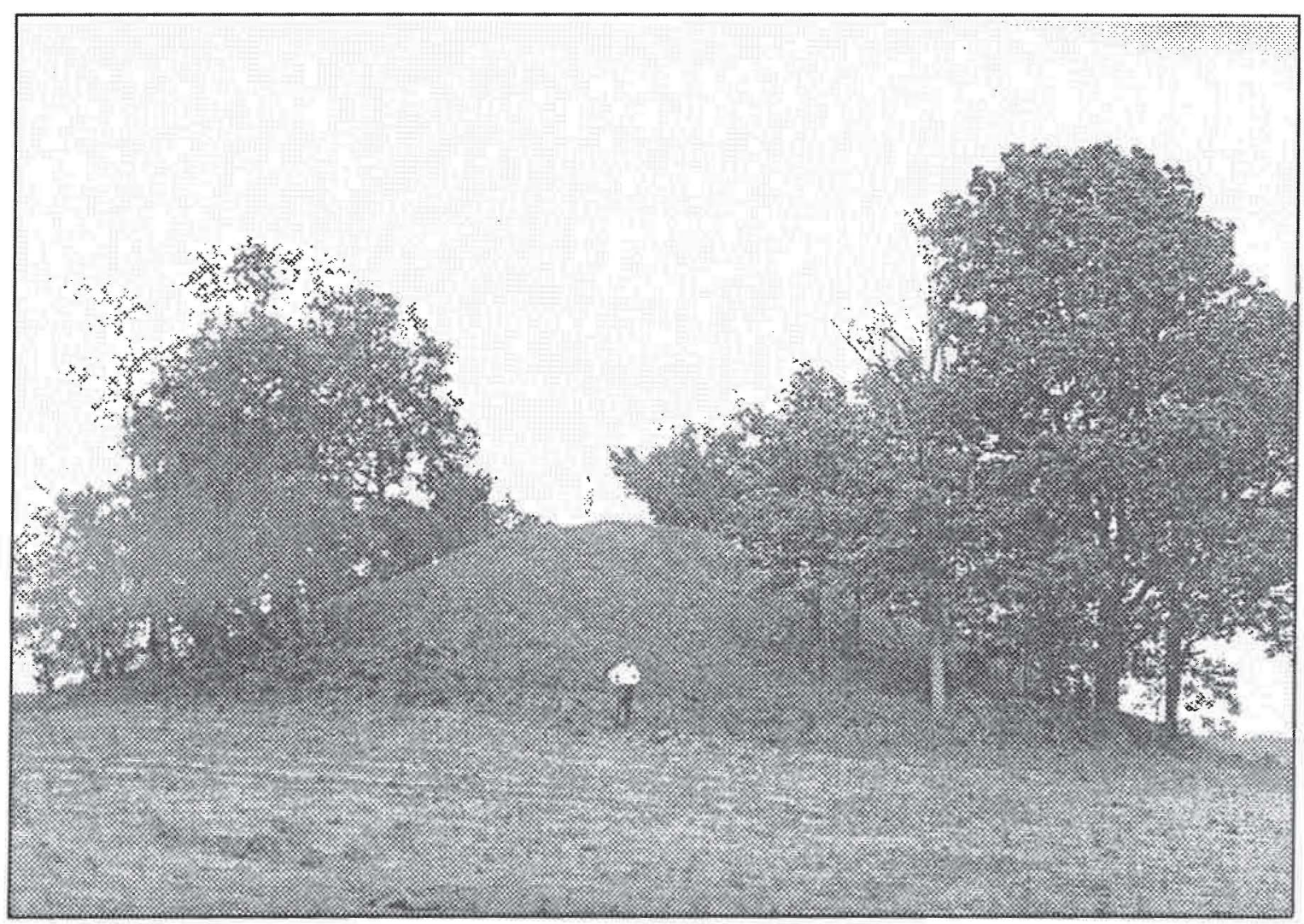

Figure 4. The Norman site (34WG2), taken in 1928, photographer unknown. Courtesy of the Western History Collections, University of Oklahoma Library. 


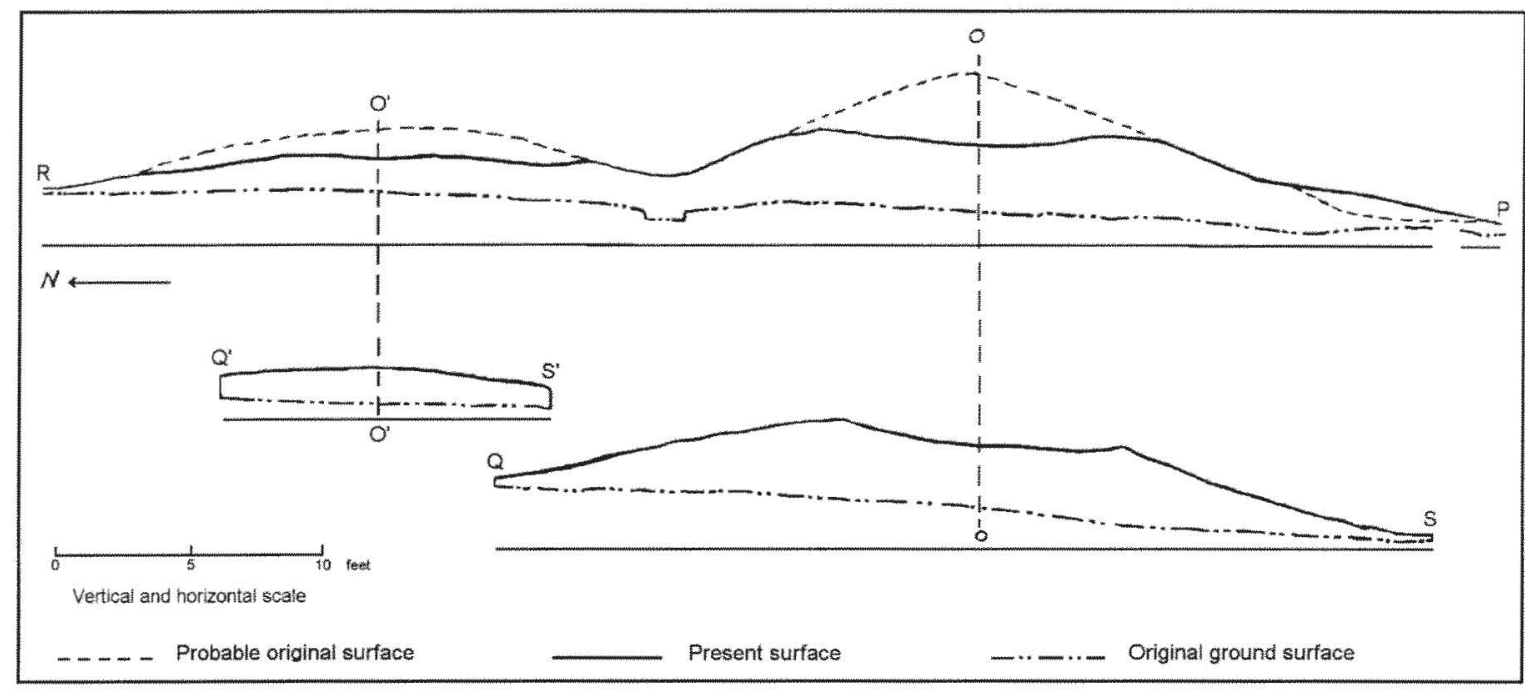

Figure 5. Profiles through Mound IA and IB; adapted from Finkelstein 1934/1935.

varies with the particular set of notes consulted) and the smaller mound six to seven feet high and 100 to 110 feet in diameter; the low, connecting saddle was 25 feet long (Finkelstein and Bell 1950:8). Figure 5 shows profiles through both lobes of Mound I, adapted from sketches made by Finkelstein in 1934 or 1935 . Early field notes state that Mound Ia was heavily vegetated, with trees up to 24 inches in diameter growing on its sides (Finkelstein 1932; Figure 4). At some time before the 1930 s, a pothunter had dug a hole in the apex of Mound Ia (Finkelstein 1932; Caldwell 1948a; Figure 5). Excavations began in 1934 with test pits and trenches placed just beyond the peripheries of Mound $\mathrm{Ib}$ (also shown as Mound $\mathrm{I}-2$ in some notes and reports). These excavations into Mound $\mathrm{lb}$ continued into 1935 as the tests revealed structural and cultural debris (Finkelstein 1934:2-3). After the excavations into Mound $\mathrm{Ib}$ were completed, excavations focused on other areas of the site, especially Mounds II and III. WPA excavations were brought to a halt by the start of World War II in 1941.

In 1948, Robert E. Bell (Department of Anthropology, The University of Oklahoma) brought students to the site for a field school. When he arrived, he found that almost the entire site, except for Mound $\mathrm{Ia}$ and the lower portion of $\mathrm{Ib}$, had been removed by heavy equipment working on the reservoir construction. Even Mound Ia had been damaged on its western periphery. The work during this summer was accomplished while fending off bulldozers. Bell called the Smithsonian's River Basin Survey for assistance in salvaging the deposits left at the site. While waiting for this help, he worked on an area to the south of Mound I (Area A) which had not been destroyed, dug a trench through the saddle between Mound $\mathrm{Ia}$ and $\mathrm{Ib}$, and began carrying this trench southward into Mound Ia. Five foot units 
were used. In mid-August, Joseph Caldwell arrived and hired a crew to help with the excavations. However, funds were not sufficient to accomplish the work by driving back trench faces through the mound from the saddle by hand. Therefore, a north-south trench 10 feet wide was dug with shovels, with a bulldozer being used to clear the summit of the mound as structures were seen in the trench. However, this tactic could only be carried out for the uppermost two substages, because money to hire workers was

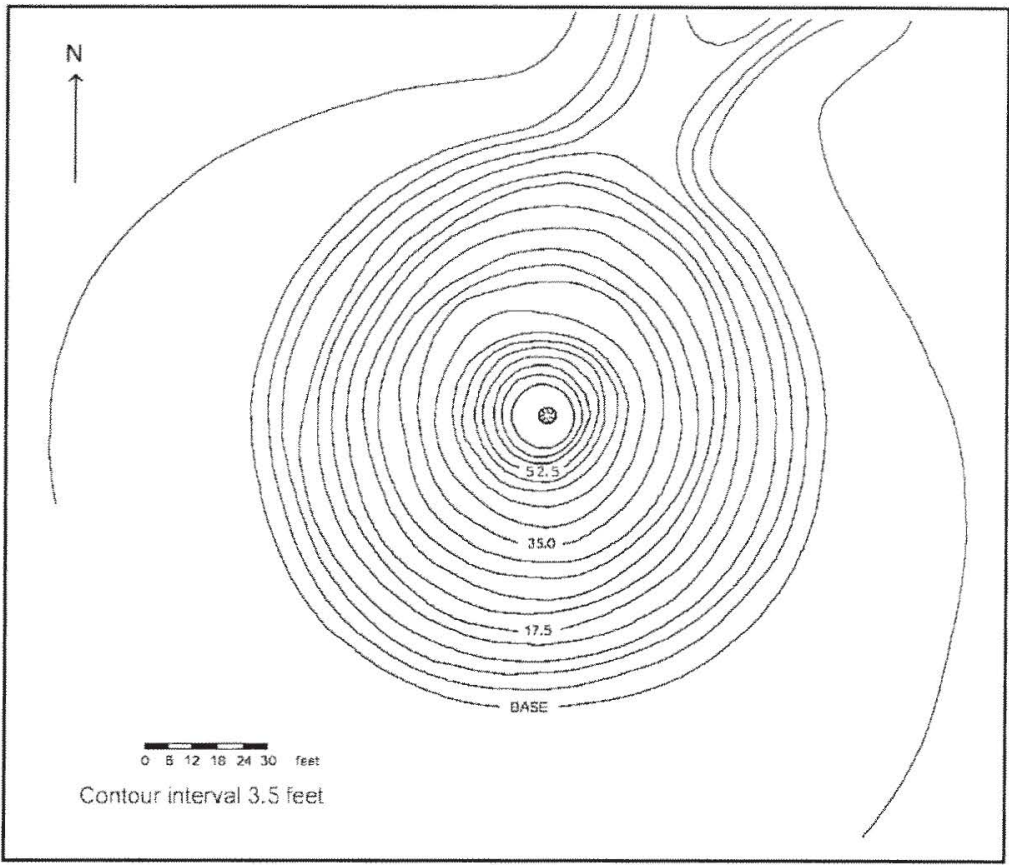

Figure 6. Contour map of Mound Ia, Norman site (34WG2); adapted from Finkelstein 1934/5.

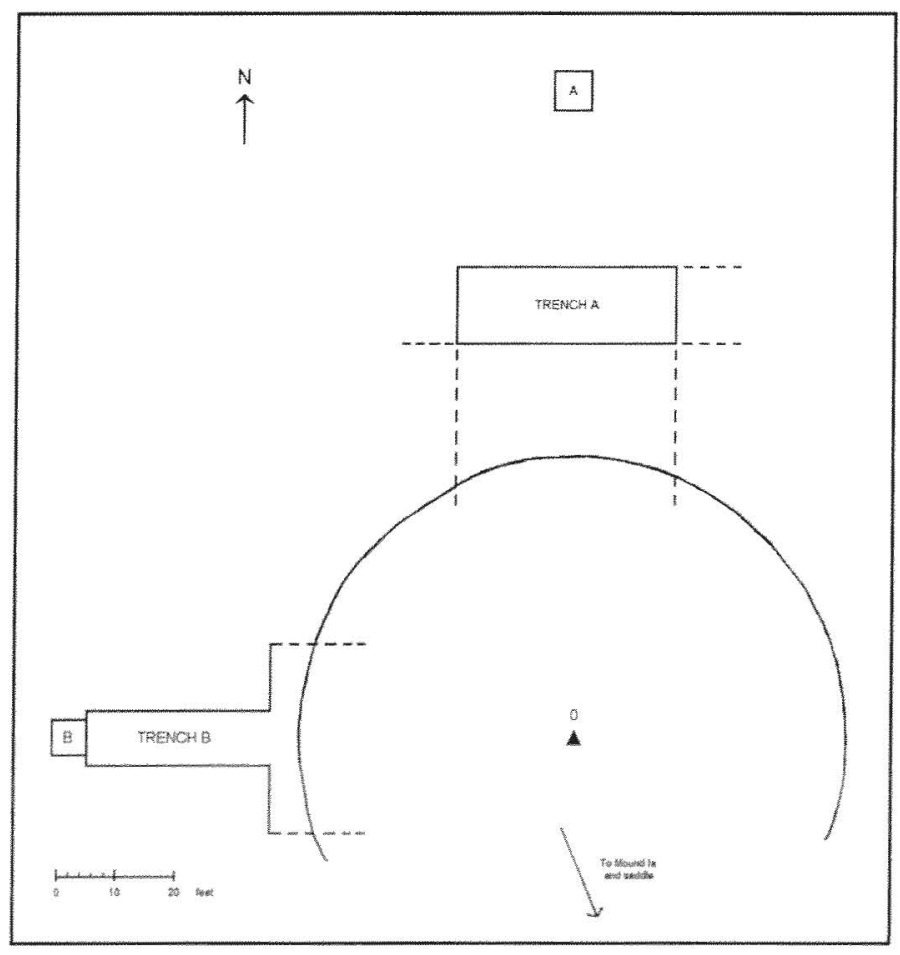

Figure 7. 1934 and 1935 excavations into Mound 16 , Site Unit $I V$, and Site Unit $V$, Norman site (34WG2): reconstructed from Finkelstein 1934/5. very scarce. For the lower substages, only the deposits in the trench were studied. Sometime during the summer, a rough contour map was made of Mound Ia (Figure 6 ). This was the only contour map made, or at least surviving, for the site.

\section{Mound Ib}

In 1934, two test pits (A and B) were dug to "determine the underlying natural stratum" (Finkelstein 1934:1; Figure 7). Test pit $\mathrm{A}$ was reported to be 100 feet north of the hypothetical center of this lobe of the mound (Point " $0 "$ ), although it was not specified whether this was 100 feet measured with a surveying instrument, a tape, or pacing, or whether it was 100 feet on the level or 100 feet on an 


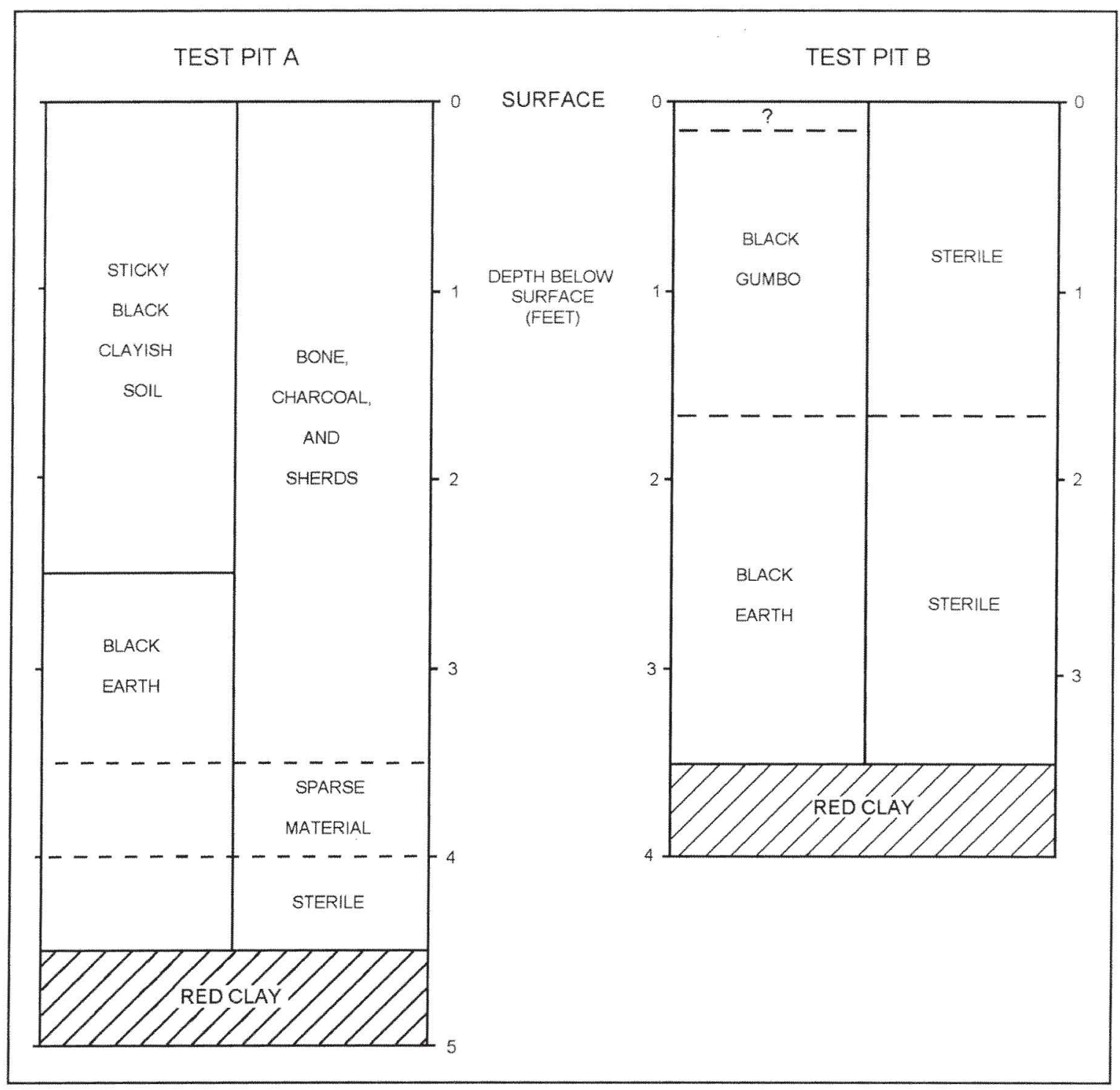

Figure 8. "Profiles" of Test Pits A and B, Mound IB, Norman site (34WG2). Reconstructed from Finkelstein's (1934) field notes.

feet on the level or 100 feet on an angle to the top of the mound. The test pit was about six feet square and reached a red clay at about $41 / 2$ feet. Brief descriptions of the soils encountered in the pit were included in Finkelstein's notes; these have been used to reconstruct "soil profiles" (Figure 8). Some cultural debris was found during the excavation. Test pit $B$, 80 feet west of Point " 0 ", reached the underlying clay at $31 / 2$ feet (Figure 8 ). No cultural debris was found in this trench.

After the completion of the test pits, trenches $\mathrm{A}$ and $\mathrm{B}$, from the north and 


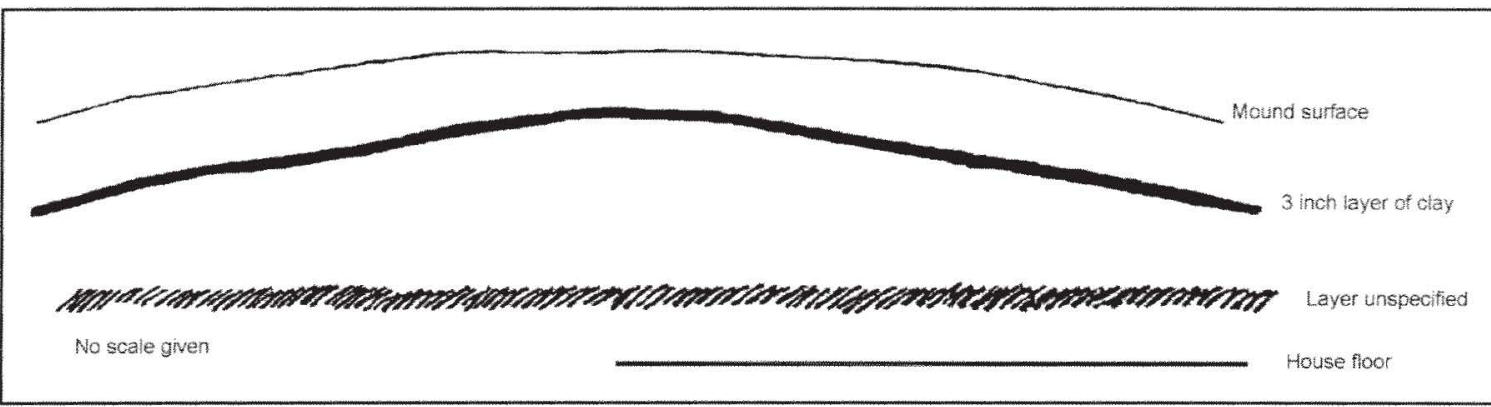

Figure 8. "Profile" of Trench B at 36 feet west of Point " 0 ", Mound Ib, Norman site (34WG2); adapted from Finkelstein 1934/5.

Although it was never specified in the notes, these trenches were apparently dug to or into the "clay stratum", because depths are described in terms of this clay marker. Trench A was thirty feet wide and began about 75 feet north of Point "0". At 63 feet north of Point " 0 ", the trench was $51 / 2$ feet deep, with bone and charcoal present to within a foot of the clay. When the floor was cleaned, postholes were seen extending into the red clay. Thin sand layers which could have defined floors or, more likely, mound construction episodes, were also noted. The posthole patterns will be discussed as House Unit IV. Plans for further trenching into the mound from the north were abandoned after this house unit was exposed.

Structures: House 1, Mound $I b . \quad$ A well defined house floor was uncovered about 36-38 feet (measured from the house center) southwest of Point
"0", near the mound surface (Figure 8). Although the floor was partially excavated and mapped (Finkelstein 1934), work on the structure was completed during the next season (Figure 9). The southwestern corner of the house was about a foot below the mound surface, the northeastern corner about four feet, and the other two corners between one and two feet.

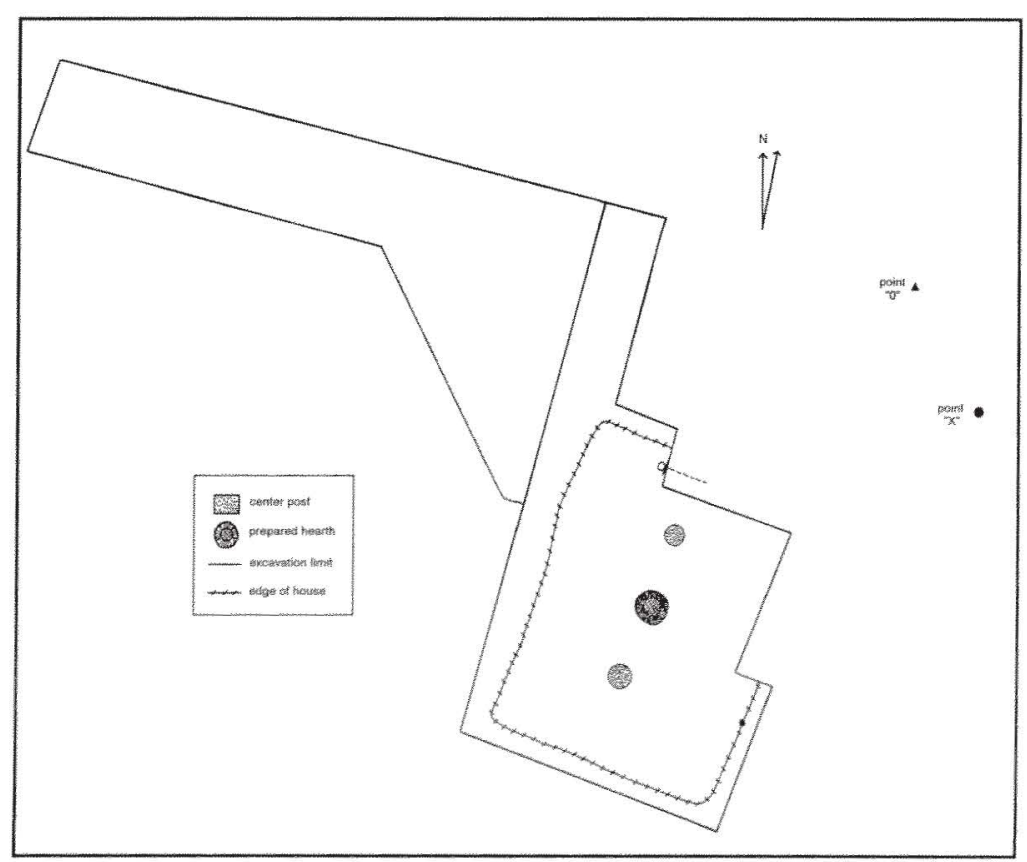

Figure 9. House 1 and Trench B excavation, 1934 season, Norman site (34WG2); adapted from Finkelstein 1934/5. 


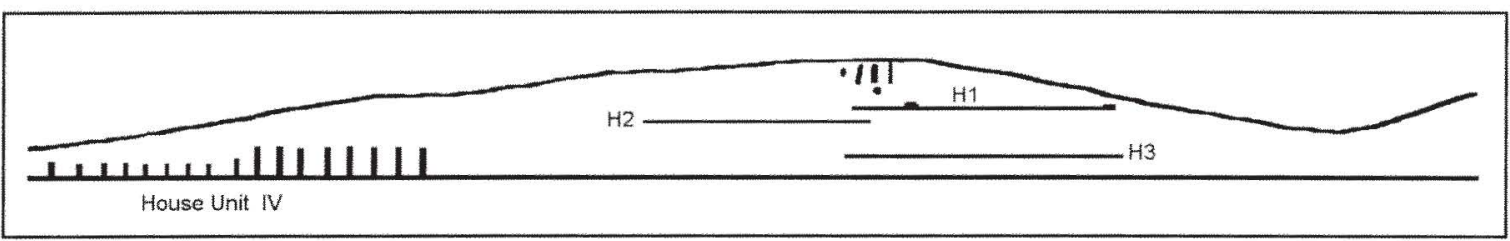

Figure 10. "Profile" through Mound Ib showing relative positions of House Unit IV and House Floors I, 2, and 3, Norman site (34WG2); adapted from Finkelstein 1934/5.

one and two feet. Removal of the fill revealed a fired, red clay floor with dimensions of $291 / 2$ by 22 feet. The long axis was oriented just east of north. Around the periphery of the floor was a raised ridge of clay about three inches high and eight inches wide. The postholes were located just within the raised rim. These postholes averaged four inches in diameter, ranged from eight to 16 inches in depth, and were spaced about a foot apart. In the eastern wall was an extended entryway about $21 / 2$ feet wide and at least three feet long. Interior features included an ash filled, central hearth with a raised clay rim. The hearth diameter was about 30 inches and depth about four inches; the rim extended about one inch above the floor. Two center posts flanked the hearth along the "north-south" axis of the structure. Each was about six feet from the center of the hearth. The posts were quite large, about two feet in diameter and were set at least $21 / 2$ feet deep.

Although no charred posts were found in place within the postholes, short post segments lay on the floor near the edge of the wall, extending into the room. The fragments averaged three to four inches in diameter. In addition, charred grass, split and whole cane, and small twigs covered the low clay rim and projected into the inner edge of the room. Pieces of fired clay (daub), some as thick as two or three inches, covered large areas of the floor and filled, at least partially, many of the postholes. Cane or twig impressions were present on many of these pieces.

Above the charred and fired materials covering the floor was a layer, four to five inches thick, of unfired red clay. This layer extended indefinitely beyond the outer edge of the house. Because the full extent of this layer was not determined, it is not certain whether this was unfired daub from the house or a clay cap laid down to mark a mound stage. However, because the charred material and fired daub did not extend beyond the raised clay rim of the house, it is likely that the clay was a mound cap. The only cultural materials associated with this house were a small, smooth piece of sandstone and some charred seeds.

Structures: Houses 2 and 3. Two other prepared clay floors covered with wattle were seen in the trench face below House 1 (Figure 10). Neither was uncovered. A workman preparing a profile of the trench face sank a pick into a mass of charred maize kernels; this mass showed the imprint of a coiled basket on the bottom. The mass was apparently from the edge of 


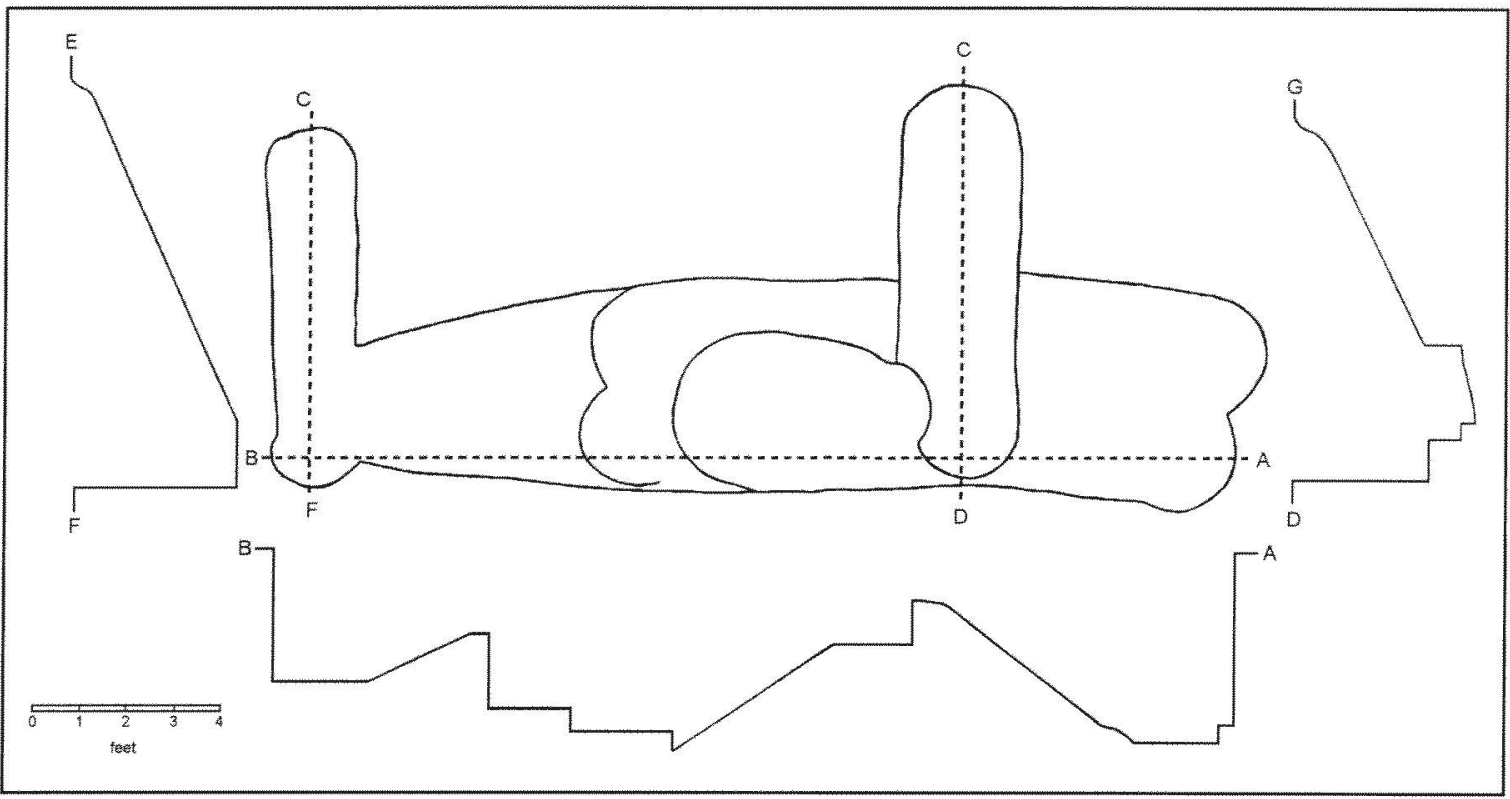

Figure 11. Profile and plan views of central "cache" pits, House Unit IV, Mound Ib, Norman site (34WG2); adapted from Finkelstein 1934/5.

the floor of House 2. A date was run on some of the corn kernels from this mass (Rogers, Albert, and Winchell, this volume).

Structures: House Unit $I V$. This series of overlapping structures was found within a 30 foot wide and 10 to 12 foot long section of Test trench A (Figure 10). In the preliminary reports, this was identified as a single structure with rooms or corridors and central caches (Finkelstein 1934/5) or as a main structure with parts of other structures (Finkelstein 1940:10-12; this volume, p. 18, Figure 12), which had been "repaired or rebuilt several times". The "caches" were actually features dug to erect and hold large center posts. As can be seen in Figure 11, they were the results of multiple construction episodes. No prepared floors were noted for these structures during the excavation. No charred posts were found, although the fill in several postholes in the southeastern corner of the excavation had a yellowish tinge of decayed wood (Finkelstein 1934/5:7). A few postholes in the southern end of the excavation were hollow. In only a few instances could posts be distinguished in the trench walls during excavation; the dark fill in the postholes was of "practically the same color and texture as the wall of the post holes" (Finkelstein 1934/5:7). The postholes varied in size from five to twelve inches. The depth of their penetration into the clay subsoil varied from about three to twelve inches, which may also reflect the multiple construction episodes for several buildings rebuilt at approximately the same location, but at differing depths as mound surfaces were covered with fresh deposits. 


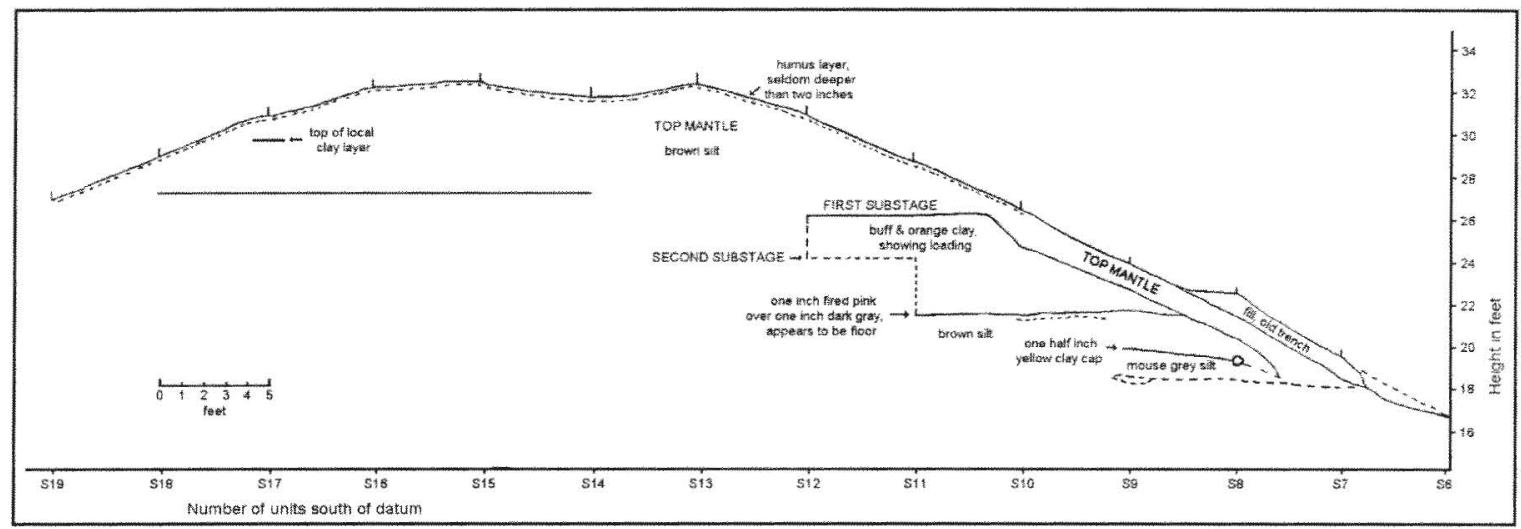

Figure 12. Profile of L8, Mound Ia, Norman site (34WG2); adapted from Caldwell 1948 .

Finkelstein thought that the main structure lay on the original (prehistoric) ground surface, about one foot below the 1930s surface and 13 inches above the clay subsoil. At the southern end of the trench, it was covered by the periphery of the mound at a depth of about five feet. However, the preliminary report by Finkelstein (1934/5:15) stated that the southern end of the house unit was "approximately a foot higher than the northern end", or about 21 to 23 inches above the clay stratum. This may be additional evidence for the presence of structures from multiple mound construction episodes. Walls or corners of additional structures, at least three, were noted in the northeastern corner of the excavation area around House IV, but were not dug (Finkelstein 1940a:8). These structures "were built on practically the same level as the structure excavated".

\section{Mound Ia.}

Bell began work in this area by digging a trench from the saddle southward into the mound (Caldwell 1948b). North-south profiles (Figure 12) were made soon after Caldwell's arrival, as well as a profile of the upper portion of the southern wall of the trench (Figure 13). Further excavations under Caldwell's supervision (1948a,b) revealed that this mound consisted of a series of platforms (substages) with a conical mantle placed over the top. The substages were number from top to bottom, not in the order in which they were constructed. At the end of Caldwell's work, the trench through the mound was 90 feet long and 29 feet deep.

Top mantle. The mound was capped with a seven foot deep layer of homogeneous brown silt. Its maximum diameter was about 40 feet (Caldwell 1948b:4). The mantle contained four human burials, each with only a few decomposed bones remaining. Some glass beads, fragments of bison and other bone, and fragments of mussel shell were also found. Other artifacts, such as sherds, were very sparse within the mantle. The beads were found at a depth of five feet and, according to 


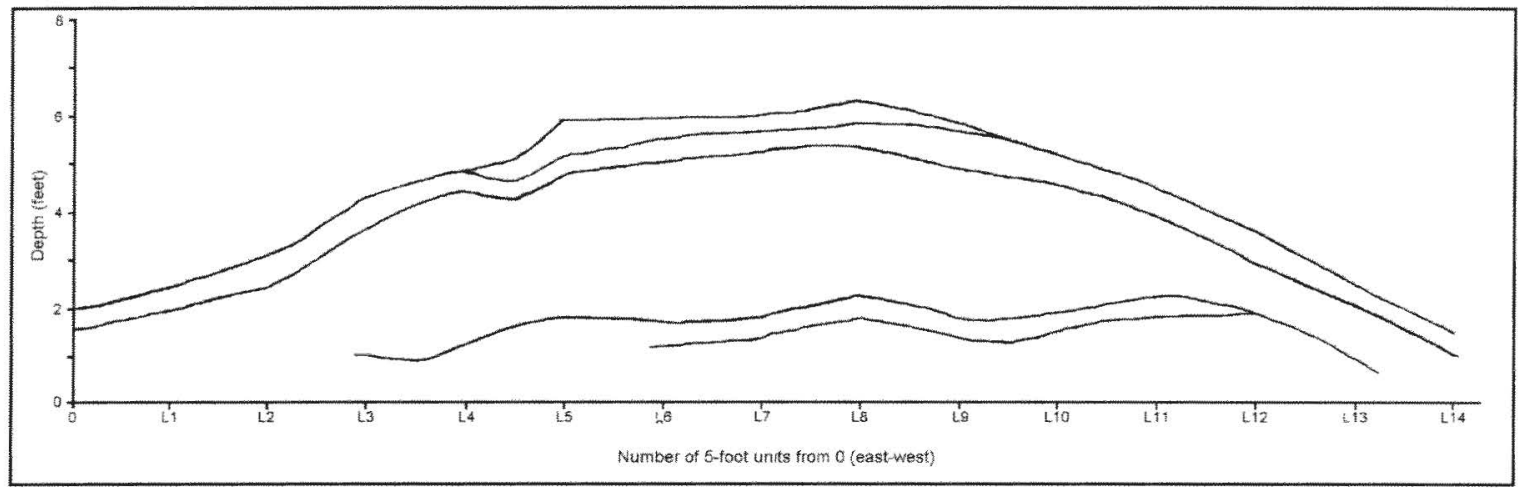

Figure 13. Profile of S6, Mound Ia, Norman site (34WG2); adapted from Caldwell 1948a.

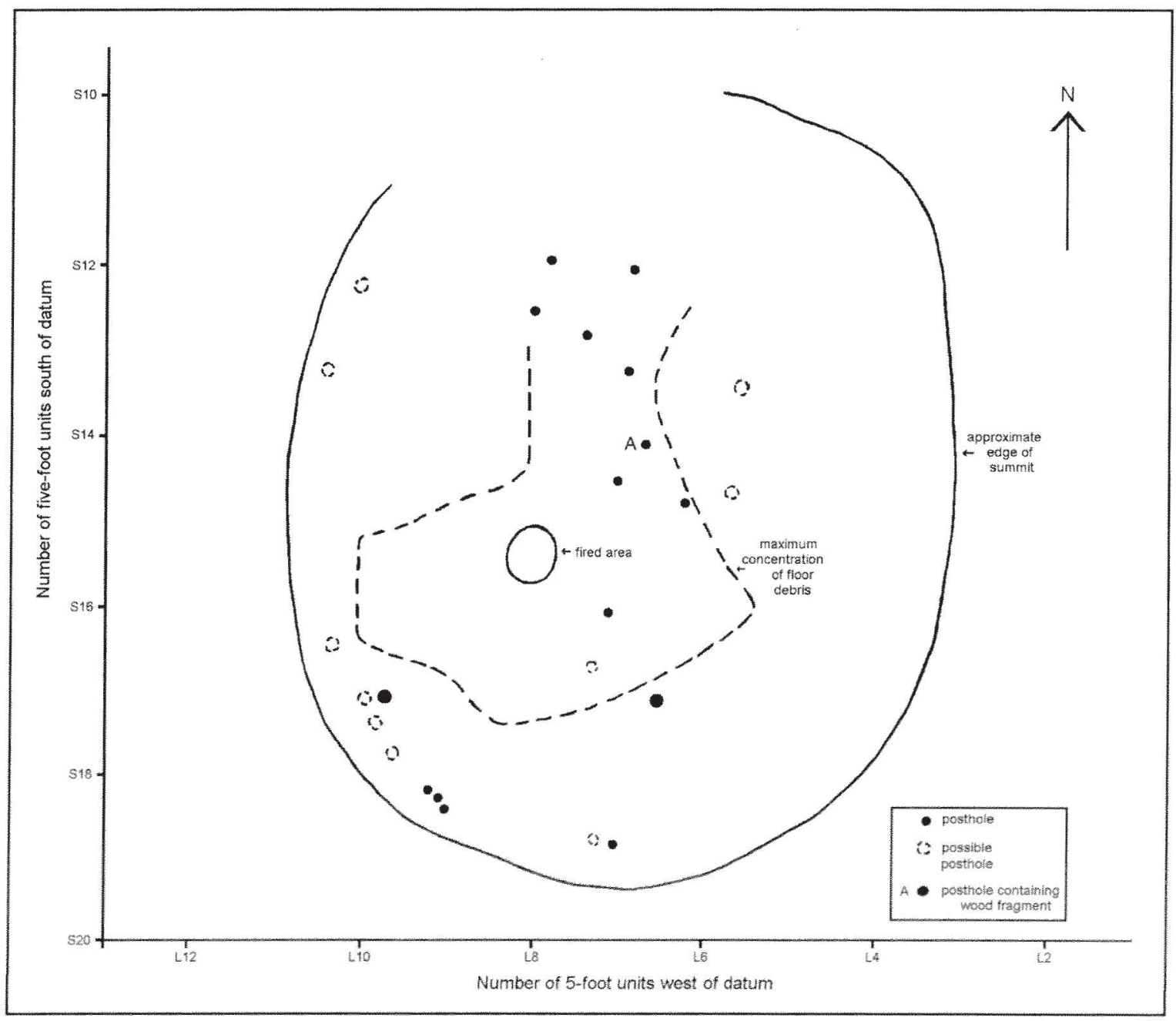

Figure 14. First substage features, Mound Ia, Norman site (34WG2); adapted from Caldwell 1948a. 


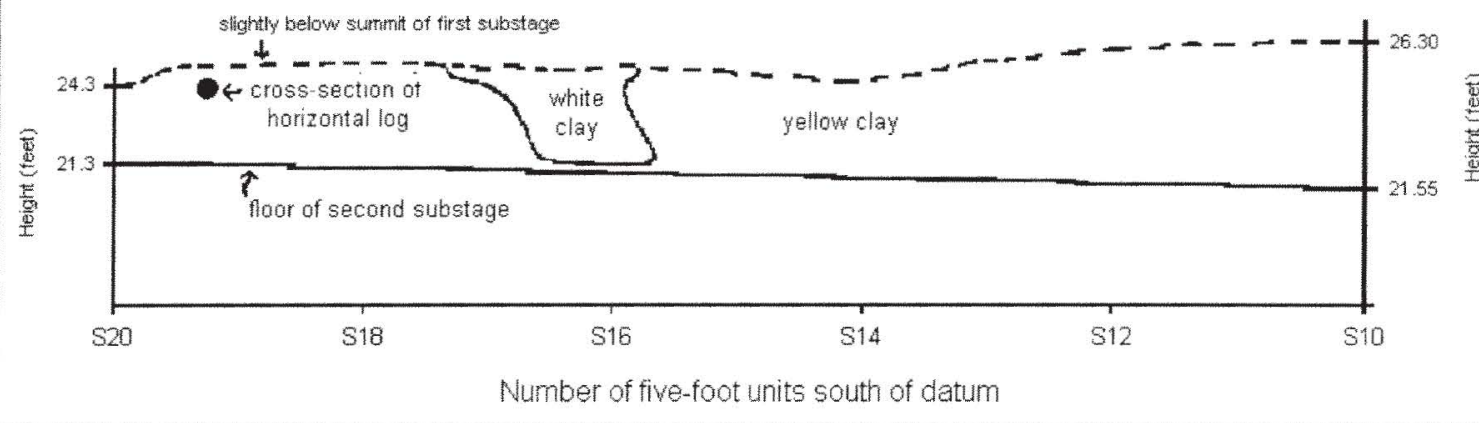

Figure 15. Profile detail, western wall of L6-L8 trench, Mound Ia, Norman site (34WG2); adapted from Caldwell 1948a.

Caldwell (1948b:4), were not associated with any of the burials. Obviously, some historical activity, whether associated with these human burials or not, had taken place in order for the glass beads to be deposited here.

First substage. After the majority of the mantle deposits had been removed by bulldozer, shovels and trowels were used to clean the surface of the first substage. This four-foot thick layer was built up of mottled yellow clay placed on the next lower (second) substage. The summit of this layer was covered by "a thin deposit of organically stained sand with ash admixture" (Caldwell 1948b:5). A fired area and postholes were also present (Figure 14). Although Caldwell states that the

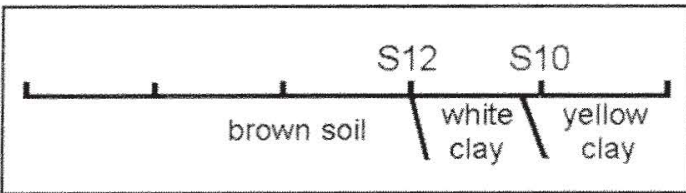

Figure 16. Profile detail, eastern wall of $L 6-L 8$ trench. Mound Ia, Norman site (34WG2); adapted from Caldwell 1948. postholes were difficult to distinguish, a line of them may have encircled the edge of the substage summit. One posthole contained wood fragments which were identified in the field as locust. A few artifacts were found in an area which was designated the occupation area; they included "clinkers", fired "wall plaster", a few mussel shells, bones, and three sherds. Below the summit of the first $\mathrm{substa} g \mathrm{e}$, C a 1 d w e 11 recorded bands of white clay abutting the yellow clay of the fill in the wall profiles of trench L6 - L8. The white clay areas may have been part of one larger feature running more
Figure 17. Possible white clay feature noted in walls of $L 6-L 8$ trench between first and second substages; from Caldwell 1948a. 


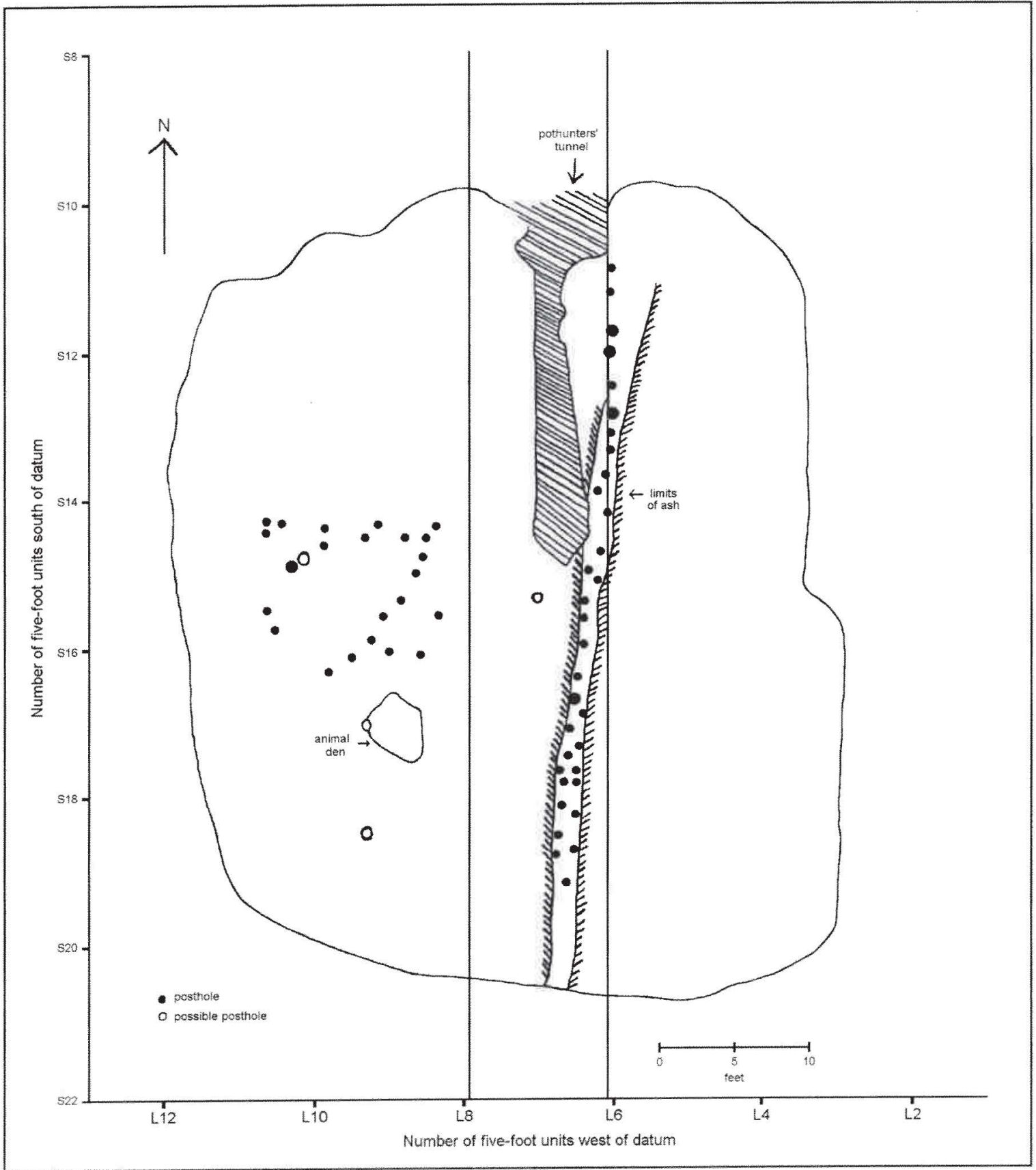

Figure 18. Second substage fatures, Mound IA, Norman site (34WG2); adapted from Caldwell 1948 a.

than ten feet, from between S16-17 on the western wall of the trench (L8) to between S10-12 on the eastern wall (L6; Figures 15 and 16). If this were indeed a feature, it would have run in a northeastsouthwesterly direction (Figure 17). 
Second substage. At the base of the four-foot thick yellow clay which formed the first substage, the effects of fire could be seen in many places (Caldwell 1948b: 5). Some of the fired areas were clumps of fallen daub. A double row of postholes dug into brown silt ran approximately north-south across the summit, dividing it into two parts. To both the east and west of this possible wall was a line of blue ash (Figures 18 and 19). Other postholes were found to the west of the possible wall; however, they formed no readily discernable pattern. Most of the postholes attributed to this substage did not

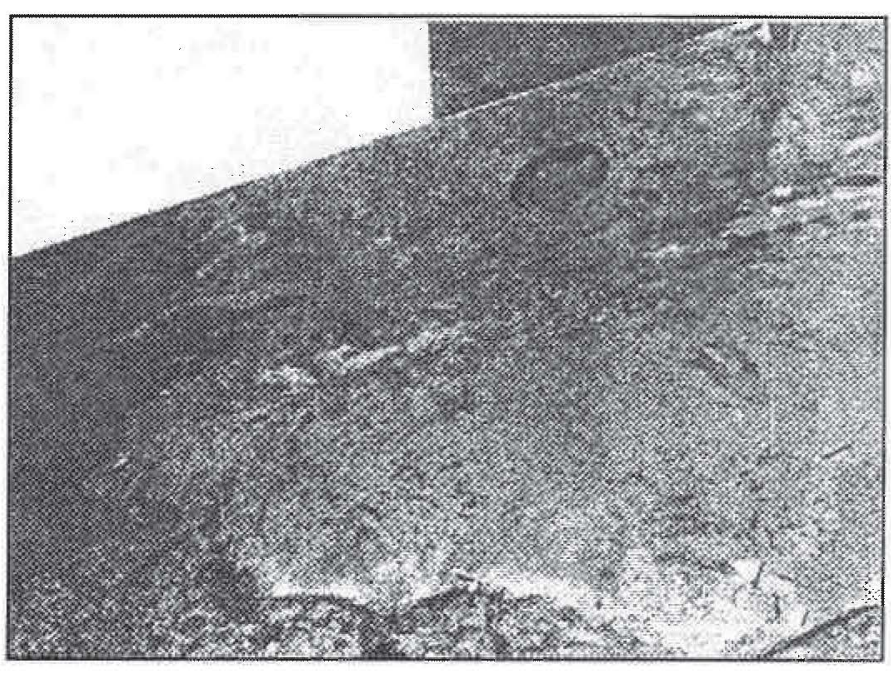

Figure 19. Second substage showing line of ash, Mound Ia, Norman site (34WG2). Photo by Joseph Caldwell; courtesy of Sam Noble Oklahoma Museum of Natural History, The University of Oklahoma. appear until the workers had cut

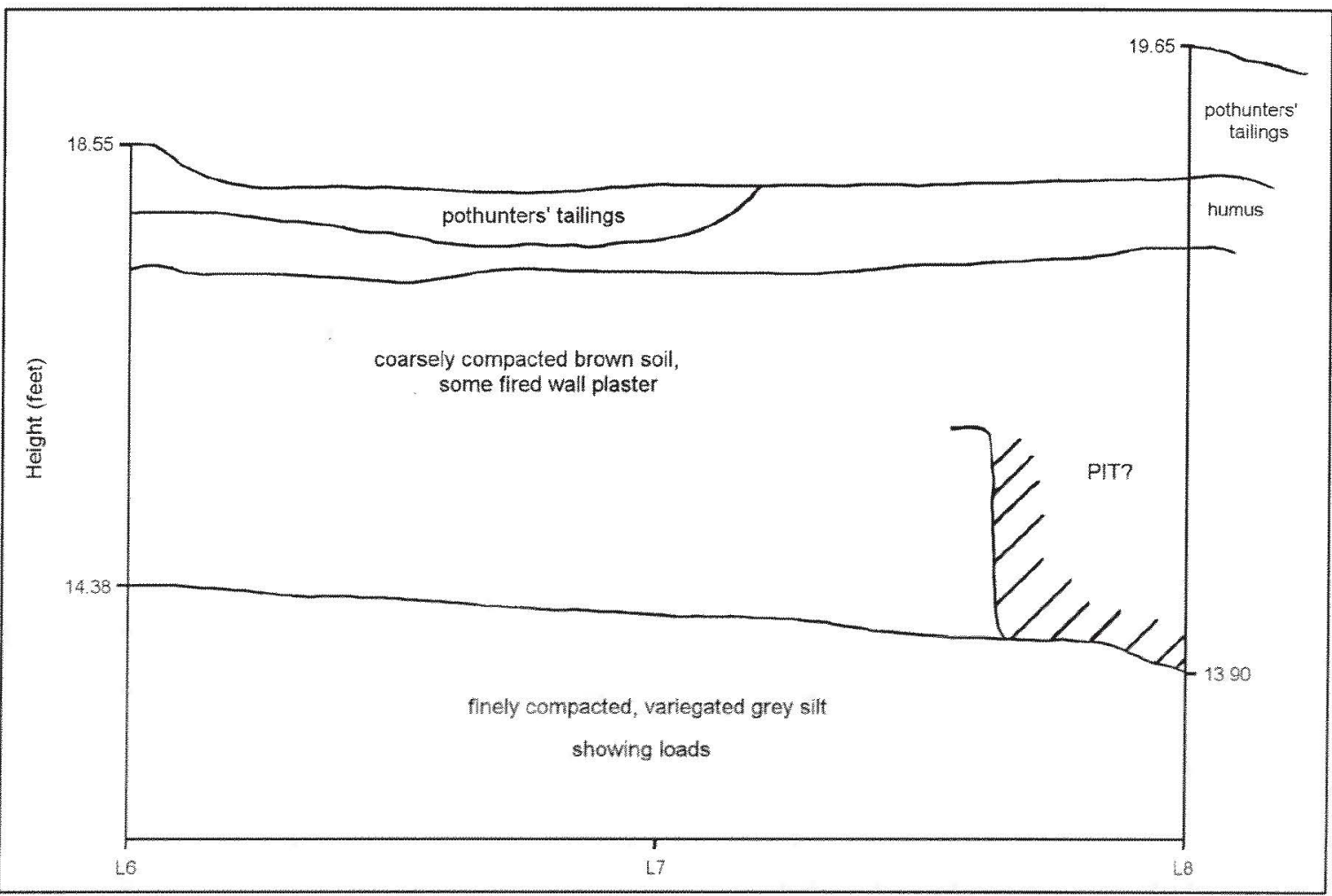

Figure 20. 57 profile, Mound Ia, Norman site (34WG2); adapted from Caldwell 1948a:August 31 notes. 


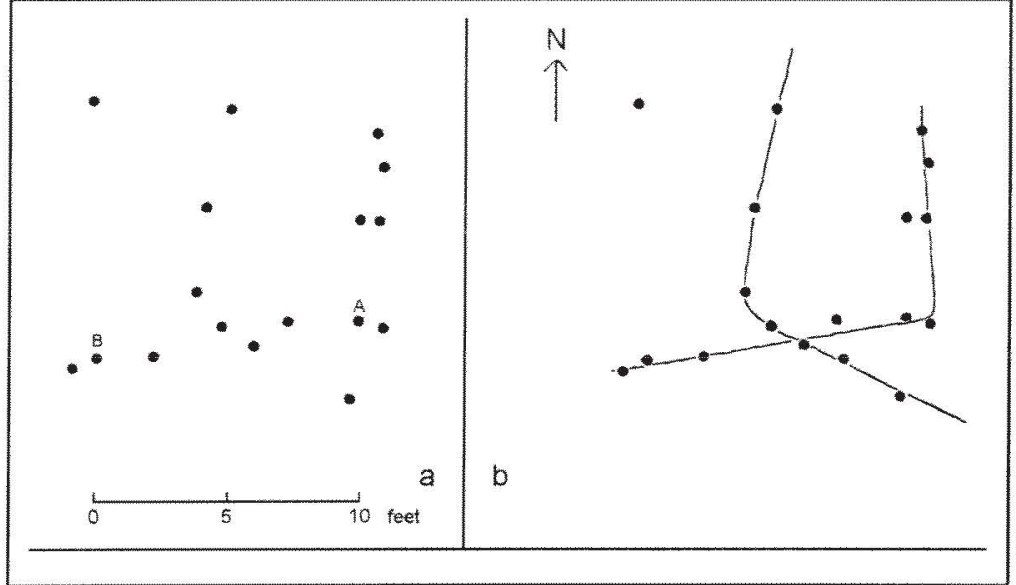

Figure 21. Postholes exposed in the L6 - L8 trench at the third substage; adapted from Caldwell 1948 . trench between the $\mathrm{L} 6$ and L8 lines and in "a small area" immediately to its west. Some postholes were found (Figure 21a); Caldwell (1948b) did not recognize a pattern. However, they may possibly be parts of at least two over-lapping structures (Figure 21b).

The fill below the third substage was composed mainly of grey and tan silts. The deposits clearly showed a striped (or "basket several inches below the substage surface, so there was possibly an additional, unrecognized surface present. However, a pothunter's tunnel had destroyed part of the surface of this substage. Some of the "tailings" from this tunnel can be seen in the $\mathrm{S} 7$ profile done on August 31 (Figure 20). In addition, the upper portion of an animal den was noted in the southwestern quadrant of the summit; the den extended into the third substage.

Third substage. The deposits below the second substage were exposed only in the 10 -foot wide

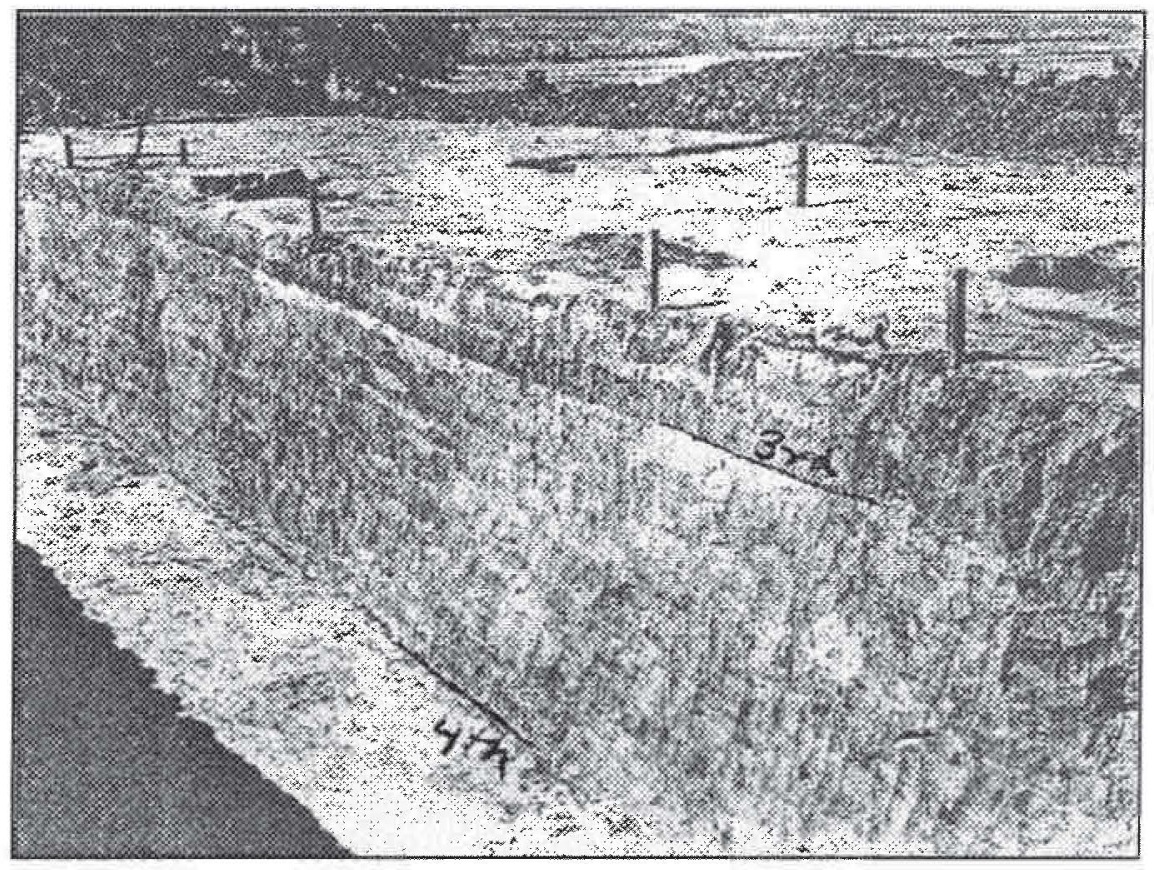

Figure 22. Fill between the third and fourth substages showing the "basket loading" in the L8 profile, Mound Ia, Norman site (34WG2). Photo courtesy of Sam Noble Museum of Natural History, The University of Oklahoma. 


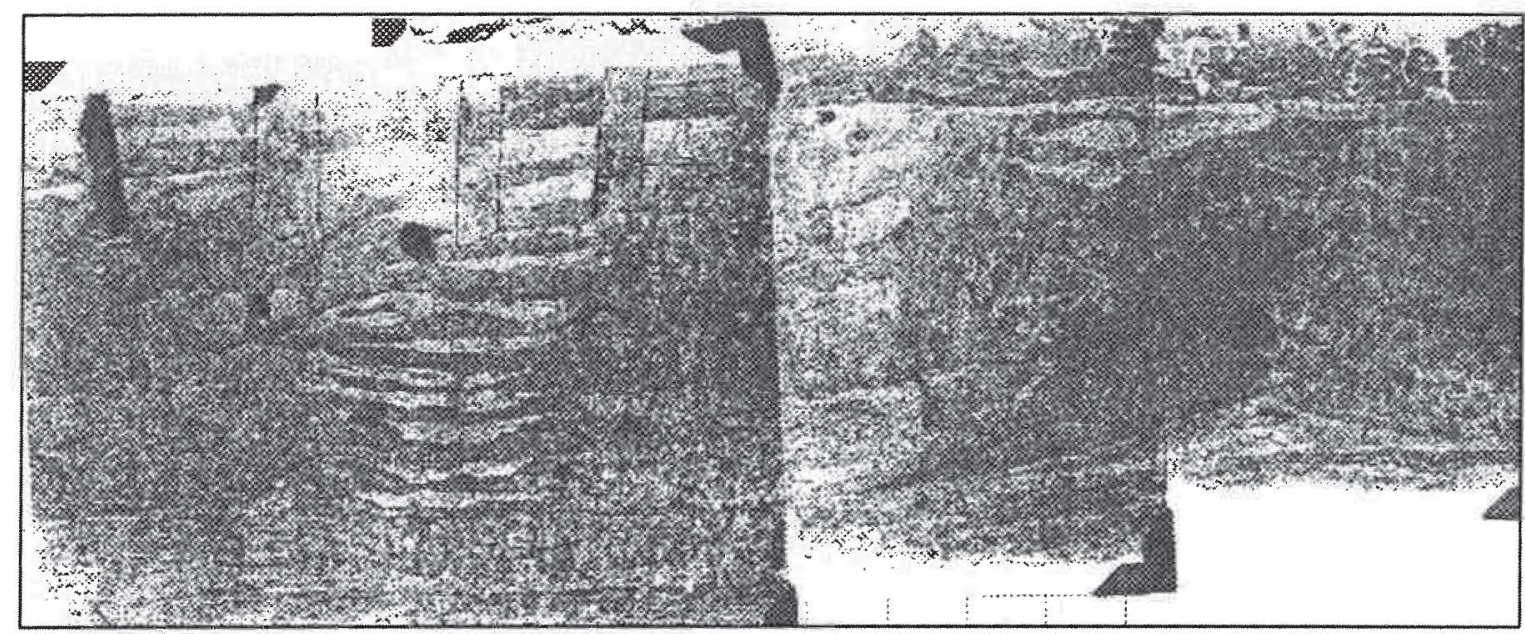

Figure 23. Closeup of "basket loading" in the fill between the third and fourth substages, Mound Ia, Norman site (34WG2). The outlined postholes are from the second substage. Photo probably by Joseph Caldwell, courtesy of Sam Noble Museum of Natural History, The University of Oklahoma.

Merletti 1989:143).

The deposits from the fill above second into the fill below the third substages were disturbed by a pot- hunters' tunnel (Figure 24). This tunnel extended southward from the northern slope of the mound, and then was dug straight down in square S15-L6 to form a vertical shaft extending into the lower substages to a point five feet above the premound surface (Caldwell 1948a). A clay "plug" from higher in the deposits, some large rocks, wood fragments, a spoon, and turtle carapace were found near the base of the shaft. Shovel marks were visible in the walls of the tunnel.

The animal den first noted at the second substage was also present in the fill between the second and fourth substages (Figure 25). This den extended westward from the L8 line westward along the S17 line, and could be seen in the L6 line between S19 and
S21. It was filled with soft, loose silt mixed with organic material, including nuts. The bottom of the den was 14 feet

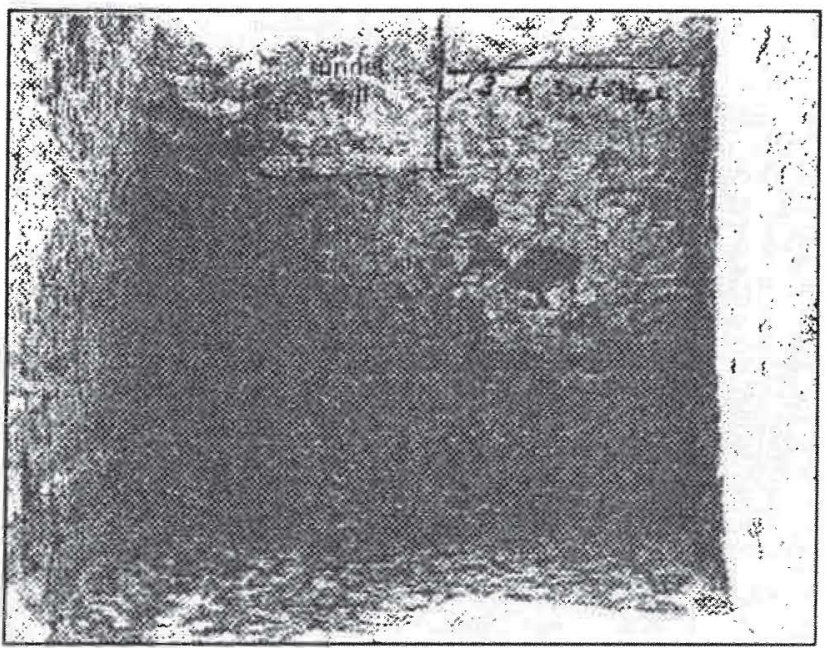

Figure 24. $S 9$ profile between $L 6$ and L8, Mound Ia, Norman site (34WG2). The vertical line is the edge of the tunnel; the fill has slipped downward into the tunnel. Photo probably by Joseph Caldwell, courtesy of Sam Noble Museum of Natural History. The University of Oklahoma. 
below the mound summit (Caldwell 1948a).

Fourth substage. Six feet of "basket-loaded" deposits separated the third and fourth substages (Figures 23 and 24). No postholes were noted on the fourth substage surface.

Fifth substage. The surface of the fifth substage lay only two feet below that of the fourth. The fill separating them consisted of grey, brown, and yellow basket loaded deposits. In the southern part of the trench, postholes were found which appeared to

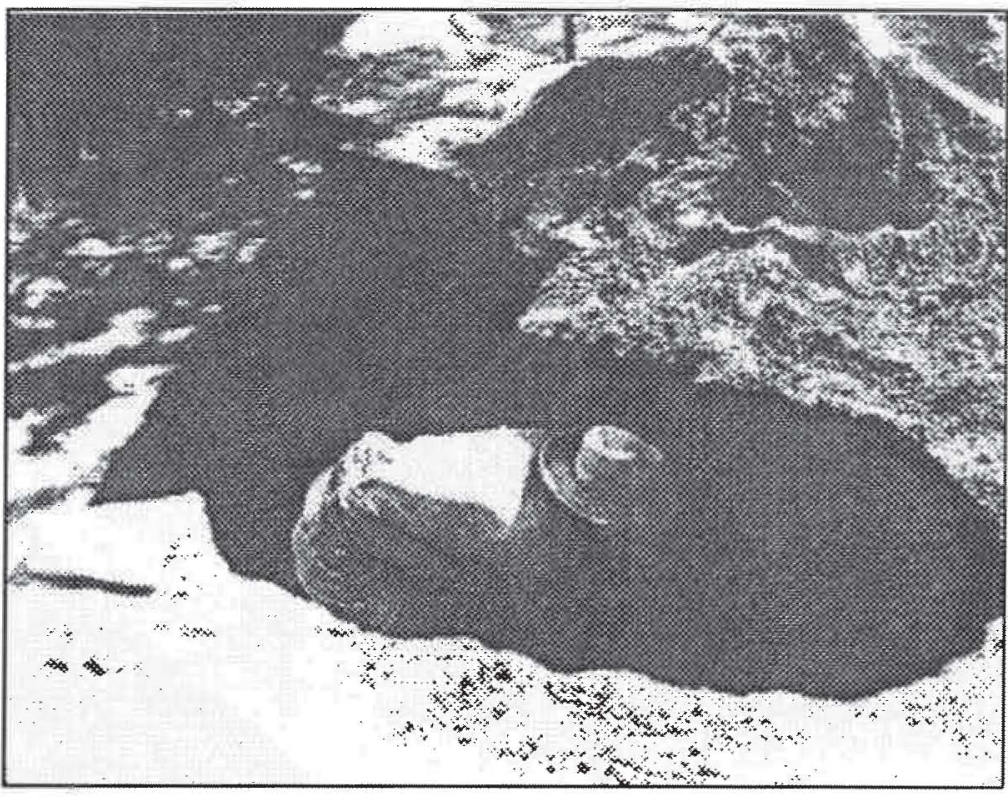

Figure 25. Probable animal den between second and fourth substages, Mound Ia, Norman site (34WG2). Photo probably by Joseph Caldwell, courtesy of Sam Noble Oklahoma Museum of Natural History, The University of Oklahoma.

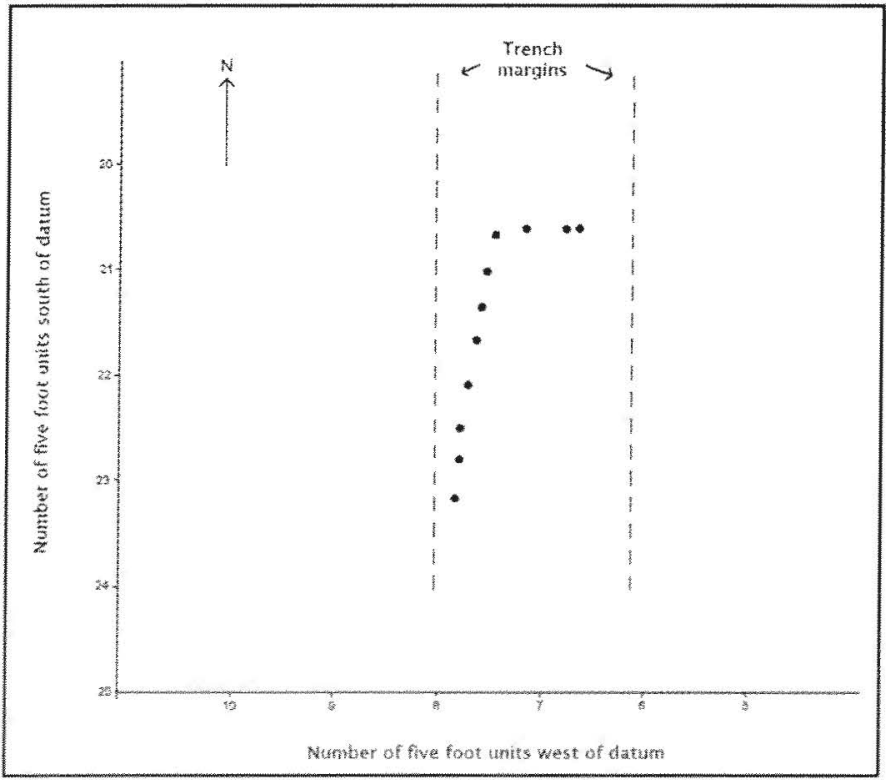

Figure 26a. Posthole pattern in the fifth substage of the L6L8 trench, Mound Ia, Norman site (34WG2). Adapted from Caldwell 1948 a. form a rounded corner of a structure (Figures 26a and 26b).

Substage?? 5A. Below the fifth substage surface lay one foot of homogeneous brown silt. This silt separated easily ("showed a good cleavage") from the deposits underlying it. Because no postholes were found in the trench, Caldwell (1948b:6) called this an intermediate level rather than a substage. These possible substages, as well as all others defined by Caldwell, can be seen in Figure 27. Some very distinct color and textural changes were present, as can be seen in the photo collages prepared by Joseph Caldwell (Figure 28). 


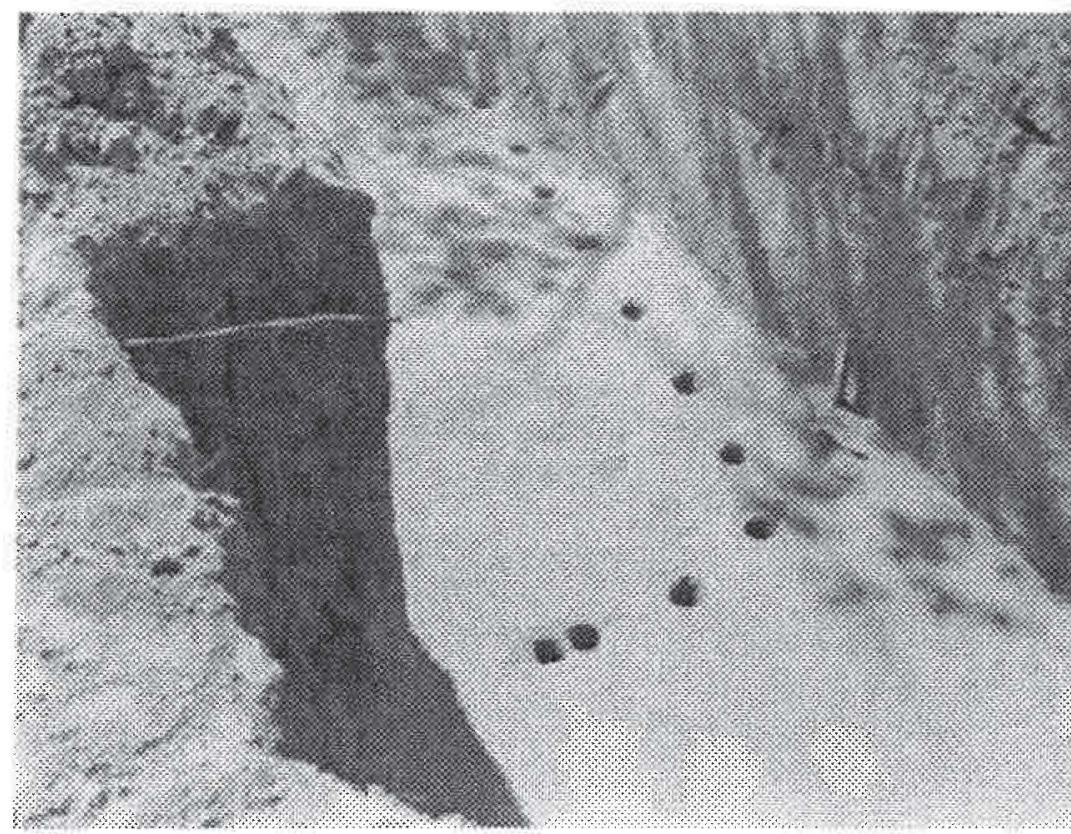

Figure 26b. Postholes at bottom of trench at Substage 5, Mound Ia, Norman site (34WG2). Photo by Joseph Caldwell (1948a); courtesy of Sam Noble Oklahoma Museum of Natural History, University of Oklahoma. from the underlying deposits and no postholes were seen on the "substage" surface. It is very likely that others were present, but not recognized using the techniques available during the limited time allowed for the work during what was essentially a salvage operation.

Premound stage. Five feet below the possible substage $5 \mathrm{~B}$ was a thin layer of charcoal and ash. The fill separating these substages was a "dark brown greasy clay containing numerous flecks of hematite". There were no postholes or artifacts correlated with this surface, but very little of it was exposed.

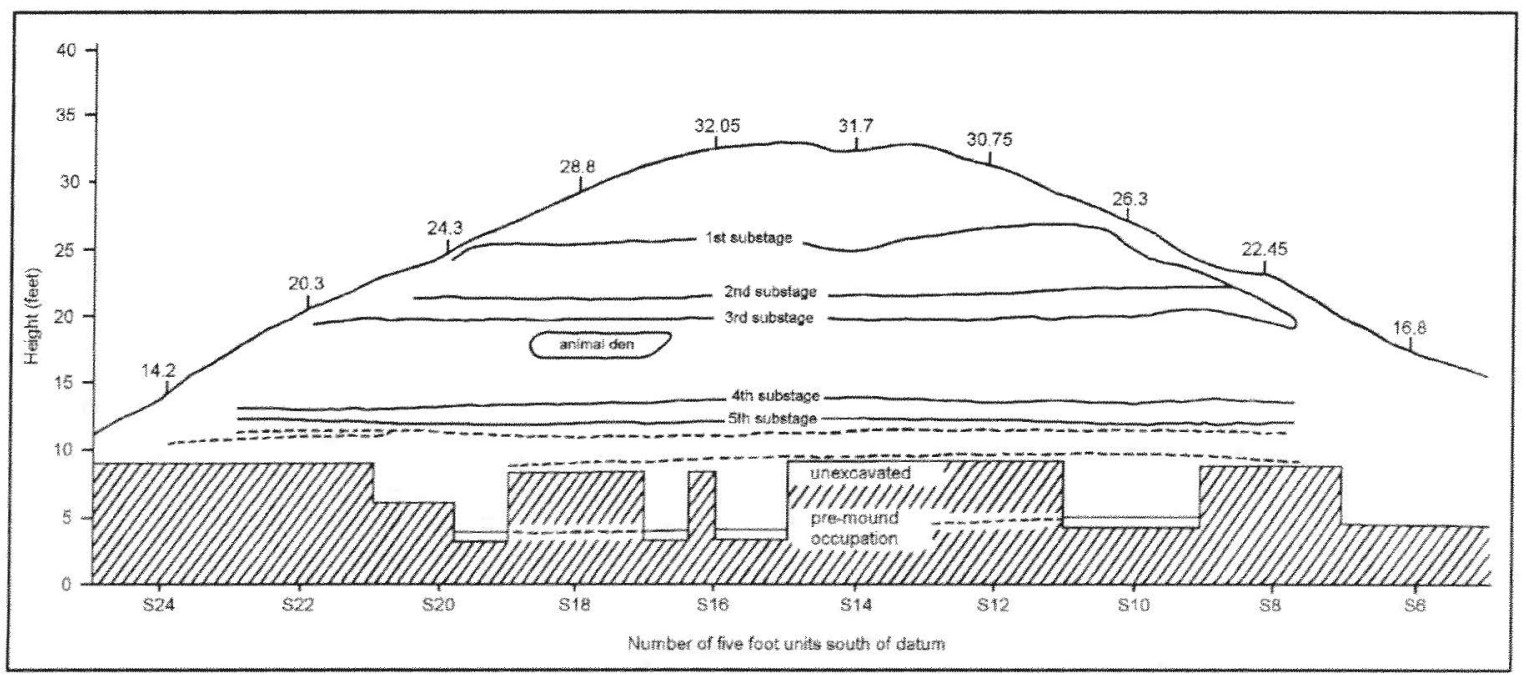

Figure 27. Reconstructed Profile Showing Recognized Substages, Mound Ia, Norman Site (34WG2); adapted from Caldwell 1948 a. 


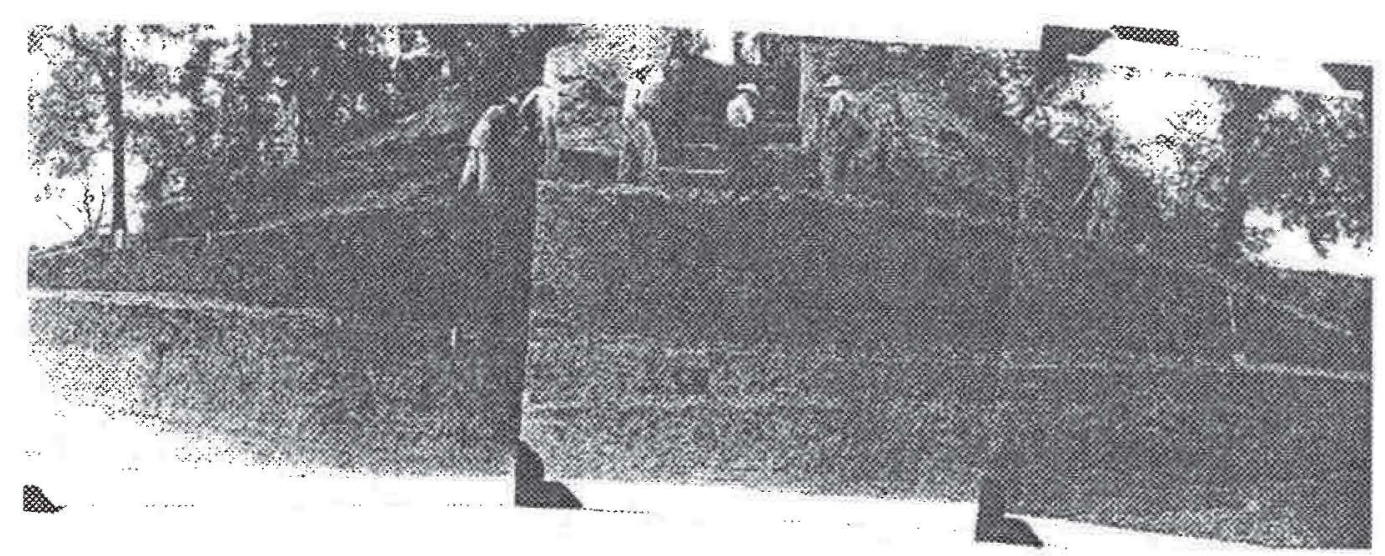

Figure 28. S6 profile through Mound Ia, Norman site (34WG2). Photo probably by Joseph Caldwell, courtesy of Sam Noble Oklahoma Museum of Natural History, University of Oklahoma.

\title{
SITE UNIT V
}

A midden area was first noted in test excavations within Site Unit IV. It was about two feet thick and about two feet below the 1930s ground surface. The soil was richer and blacker than that surrounding it. The midden was about two feet above the clay substratum, which means that it was about a foot above the level defined as the original "occupation" surface (13 inches above a clay subsoil; Finkelstein 1940b:13). This midden was traced northward about 30 feet and west- ward about 15 feet. Bones of deer, bison, rodents, birds and fish, turtle carapace fragments, "clam" shells (two perforated for use as hoes), and a few sherds were recovered (Finkelstein 1940a:9). The debris partially underlay Mound $\mathrm{Ib}$, and therefore was deposited before the mound was begun, or at least enlarged to its final extent, unless subsequent erosion of the mound had increased its diameter sufficiently to result in coverage.

\begin{abstract}
AREA A
Area A was immediately south of Mound I (Figure 29). Excavations were carried out here during the summer of 1948 during a University of Oklahoma field school under the supervision of Dr. Robert E. Bell. This area was chosen for excavation because a charcoal post was exposed by an

engineer's cut, and it was one of the few areas not completely destroyed by recent construction activity before Bell arrived at the site (Caldwell 1948b:2). The summer's work was done in cooperation with the Tulsa District, U.S. Army Corps of Engineers, and partially funded by the
\end{abstract}




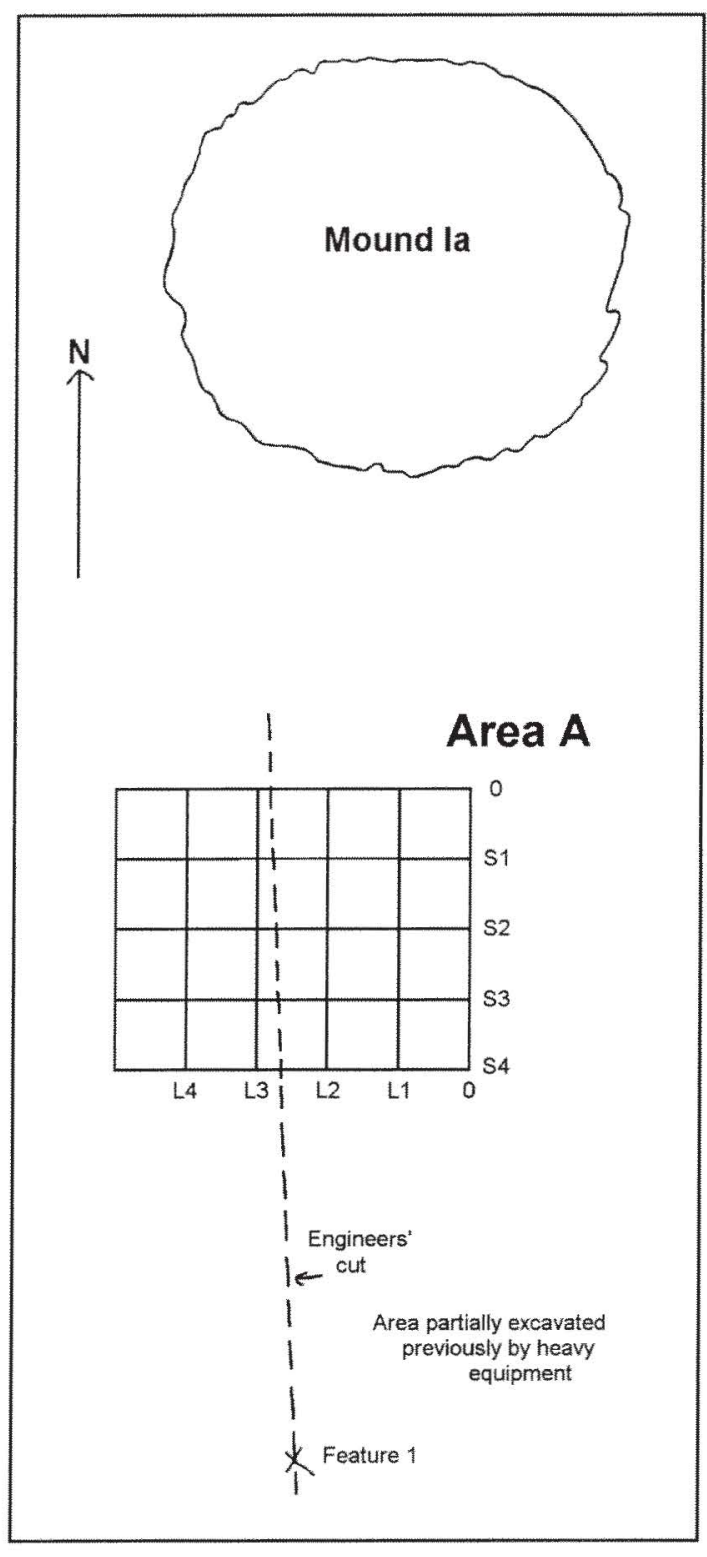

Figure 29. Map of Mound Ia/Area A portion of the Norman site (34WG2); not to scale.

Smithsonian Institution, River Basin Survey. Equipment for clearing surfaces and removing back dirt was loaned by the Evans Construction Company of Ft Smith. No photos of these 1948 excavations have been found at the Sam Noble Oklahoma Museum of Natural History.
The eastern portion of Area A had been stripped by heavy equipment to obtain fill for a nearby causeway across the reservoir. The stripping left a north-south-running cut face. A group of squares was set in south of Mound Ia (Figure 29). South of the squares, the cut was cleared, exposing a refuse pit (Feature 1, Area A, about 25 to 30 feet south of the original squares (Bell 1948b:54). Later, the enlarged excavation included this feature. The pit fill was a "dark black soil containing animal bones, chips, stones, etc.". The basin-shaped pit was roughly circular and measured 43 inches east-west by 42 inches north-south, with a clearly demarcated outline against the surrounding yellow brown soil. The animal bones included two awls, and there was also a shell pendant. The upper limit of the pit was seen at the "old plow surface" (Bell 1948b:54-55).

About 10 feet south of Feature 1, another pit (or grave) appeared as an area of brown

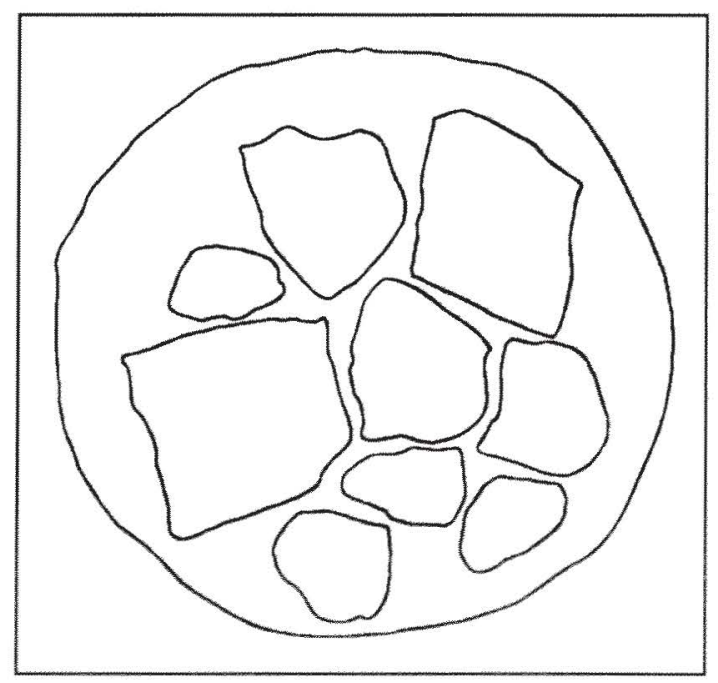

Figure 30. Feature 2, showing pit outline and rock slabs lying on pit floor; adapted from Bell 1948b:56. 


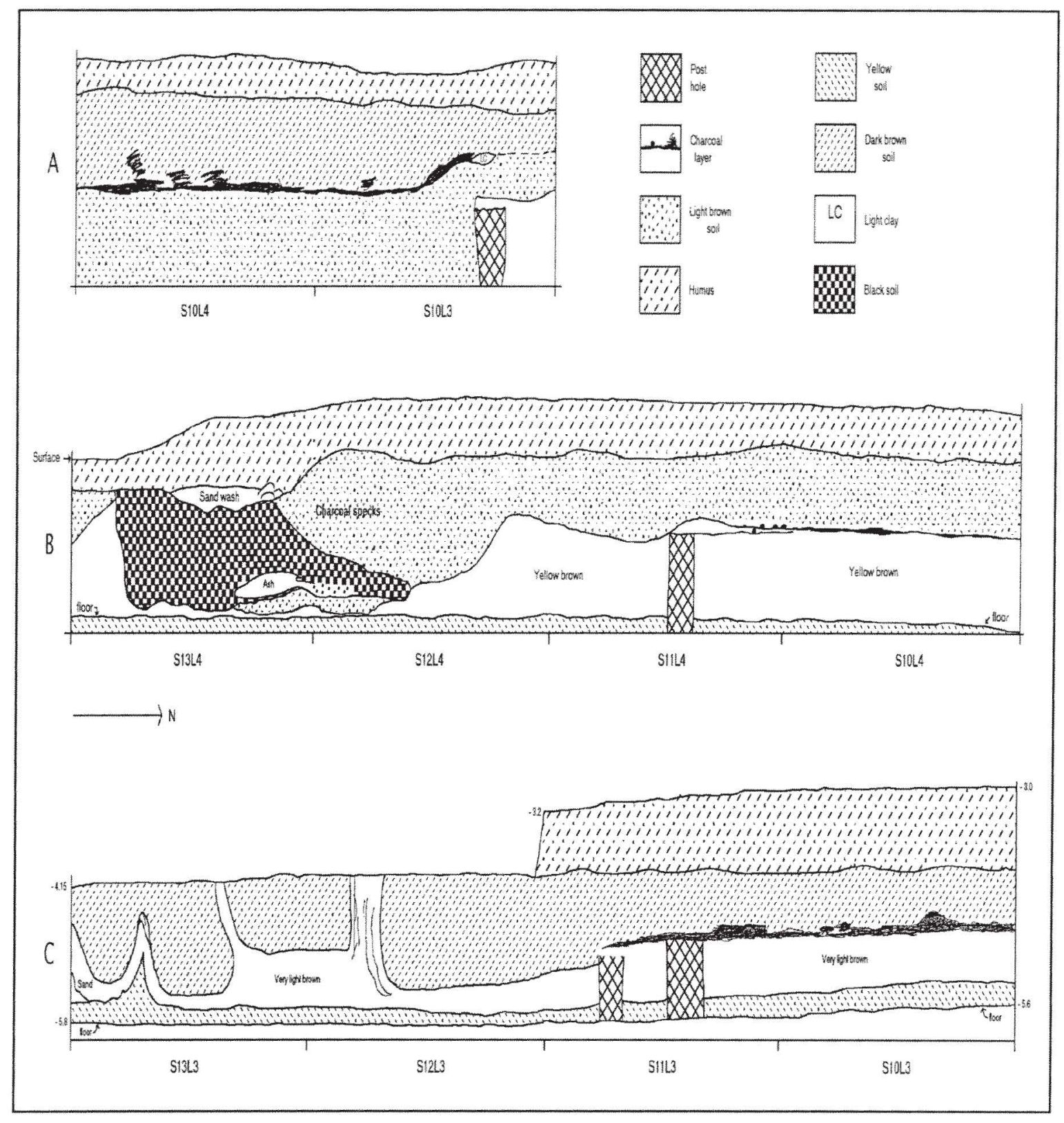

Figure 31. Profiles, Area A, Norman site (34WG2); A shows the north walls of squares S10L4 and S10L3 (July 16, 1948 by "Mac \& Hunt"), B the west walls of squares S1OLA, S11L4, S12L4, and S13L4 (July 16, 1948 by "Mac \& Hunt"), C the west walls of squares S1OL3, S11L3, S12L3, and S13L3 (July 12, 1948 by "Mac, Hunt \& Hess"); adapted from Bell 1948.

soil extending down into yellow clay (Figure 30). This was called Feature 2 (Bell 1948b:56). It contained less bone and charcoal than Feature 1. The outline was roughly circular, measured 53 inches in diameter, and was basin-shaped. On the floor of the pit, rock slabs were lying on the yellow clay (Figure 30).

Within the block of squares, an additional 


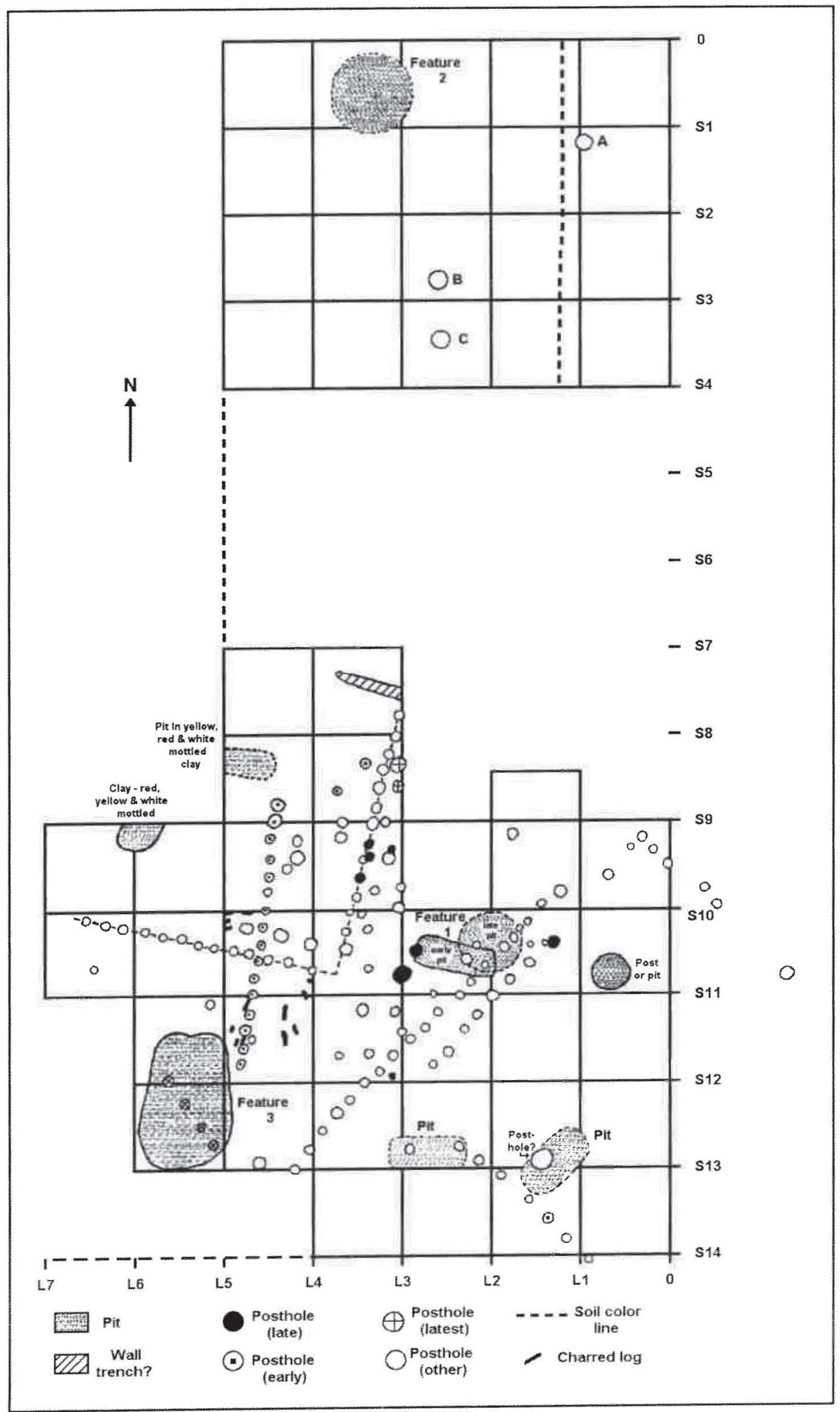

Figure 32. Map of features found in Area A, Norman site (34WG2); compiled from maps with Bell's field notes (Bell 1948b). 
six inches were excavated into the mechanically stripped construction area in an attempt to expose any features present. A pit and posts associated with a "house" floor were found in the squares (Bell 1948b:54-55,57). A layer of charcoal delineated the structure's floor (Figure 31).

Additional pits and posthole patterns were exposed in the Area $A$ squares (Figure 32). A possible wall or, more probably, entryway trench was present in S4L3. Nearby features included areas of mottled yellow, red, and white clay; that in S9L4 was in a pit. Other pits were noted, two of these (squares S11L1 and S11L2) overlapping; the subrectangular pit is the earlier. The postholes in squares S12L5 and S13L5 were found below the pit (Feature III). It was not determined whether the feature in S11 was a small pit or a large posthole. There were probably at least three building/rebuilding episodes in this area. Bell designated some postholes in a sequence of early, late, and latest. Al- though it was not specified in the notes, these designations were probably based on posthole depths. Some postholes appear to form linear patterns, probably structure walls. Diameters for some of the postholes in the west central portion of the block were included on a sketch map. In squares S11L5 and S11L6, the measurements within the row of "late" postholes were given as six and seven inches. The posthole to the south of the row in square S11L6 was five inches in diameter. In squares S8L3, S9L3, and S10L3, the diameters of postholes in the "late" row ranged between seven and eight inches. The diameters of the "latest" postholes in S9L3 were 11 and 7.5 inches. The "early" postholes in square S9L3 were five and seven inches in diameter, whereas those in square S9L4 were nine inches. Charcoal associated with "the floor of the house" was only mapped for two squares, S11L4 and S12L4 (Figure 32). This charcoal was probably post remnants from one of the overlapping structures.

\section{MOUND II}

Mound II was a double lobed unit located at the southeastern edge of the site, near a terrace edge which dipped southeastward toward a marshy area (Finkelstein, Figure A, page 8, this volume; Finkelstein 1940a: 1; Finkelstein and Bell 1950:8). It lay about 615 feet southeast of Mound III. The axis of the two circular lobes of the mound was oriented about 24 degrees west of north. The edges of the lobes overlapped somewhat. The southern lobe, $\mathrm{IIa}$, was the larger, being about 6.5 feet high and 70 feet in diameter when excavated. Finkelstein estimated that it had originally been about 10 feet high. The smaller northern lobe, IIb, was 2.5 feet high in 1934, with a diameter of 45 feet.

Excavations at Mound Unit II began in January 1934 under the supervision of J. Joe (Bauxar) Finkelstein, and were completed in April with funds provided by the Civil Works Administration (Finkelstein 


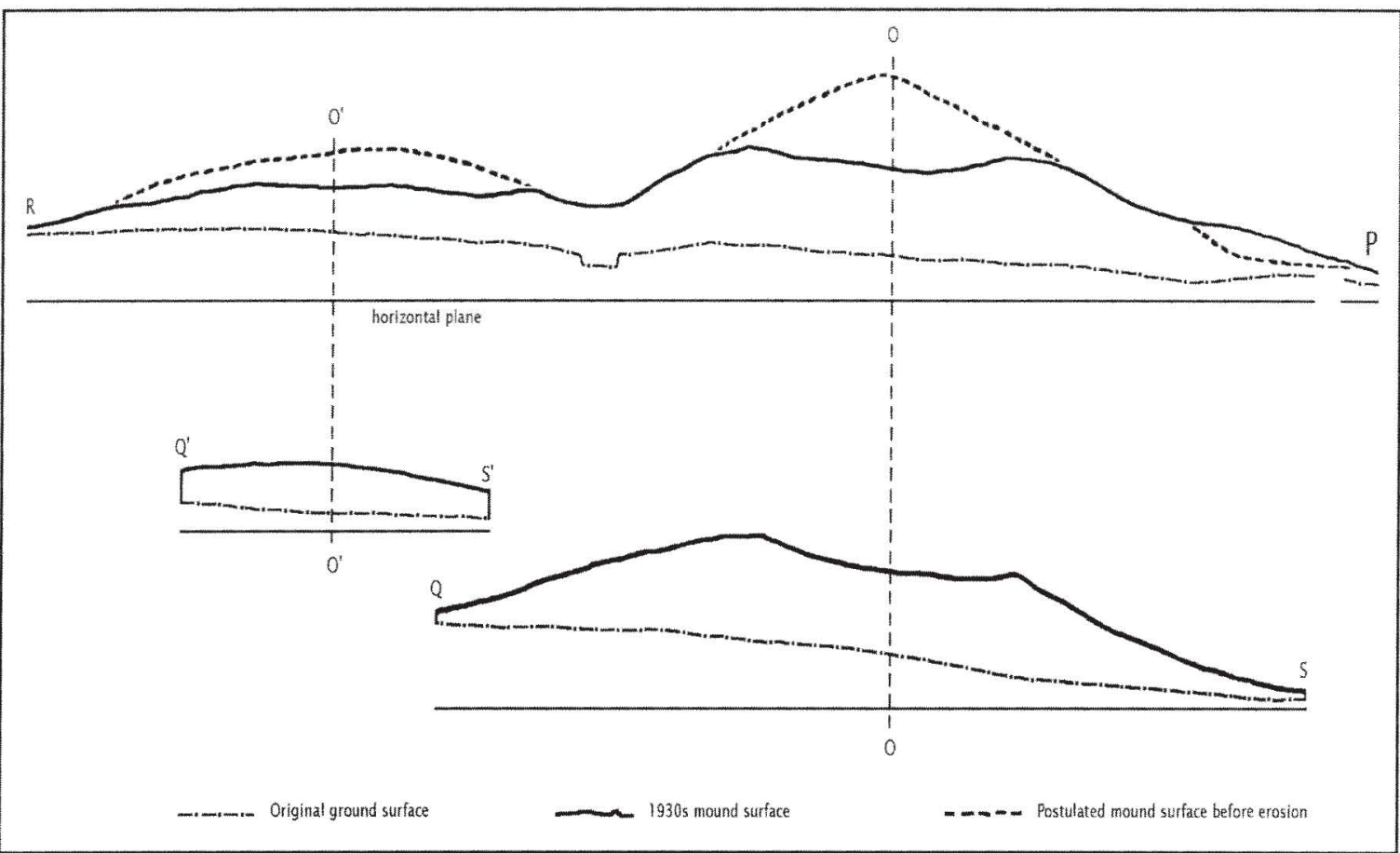

Figure 33. Profiles from Mound II, Norman site (34WG2), showing the original mound surface, the 1930s mound surface, and the postulated original mound profile; adapted from a sketch with Finkelstein's field notes.

and Bell 1950:4). The center of Mound IIa had been removed by pot hunters prior to 1932. The pot hunters' pit was about 17 feet in diameter at the top and about six feet at the bottom where it reached the subsurface gravel layer; however, by 1934 it had been refilled to within two feet of the surface (Figure 33). The eastern side of the mound had also been disturbed by two "dugouts" (Finkelstein and Bell 1950:8). Mound IIa\&IIb was completely excavated during the $1930 \mathrm{~s}$.

Under Mound IIa, the original soil zones were not clearly defined (Finkelstein and Bell 1950:11). Therefore, the excavations were taken to an underlying gravel layer. Mound Ilb was underlain by a three inch layer of black soil over the gravel. In the field surrounding the mound, the topsoil depth ranged between three and eight inches. The topsoil was underlain by about six inches of river gravel, which was in turn underlain by about six inches of red clay. Gravel was incorporated into the mound fill.

The southwestern quadrant of the mound was excavated first, by removing nine foot wide trenches aligned north-south (Finkelstein and Bell 1950:10). After digging this section, the grid was shifted slightly to coincide with the axis through the two mound lobes (Figure 34). The northwestern quadrant was then removed in 10 foot wide trenches, and the center in two 


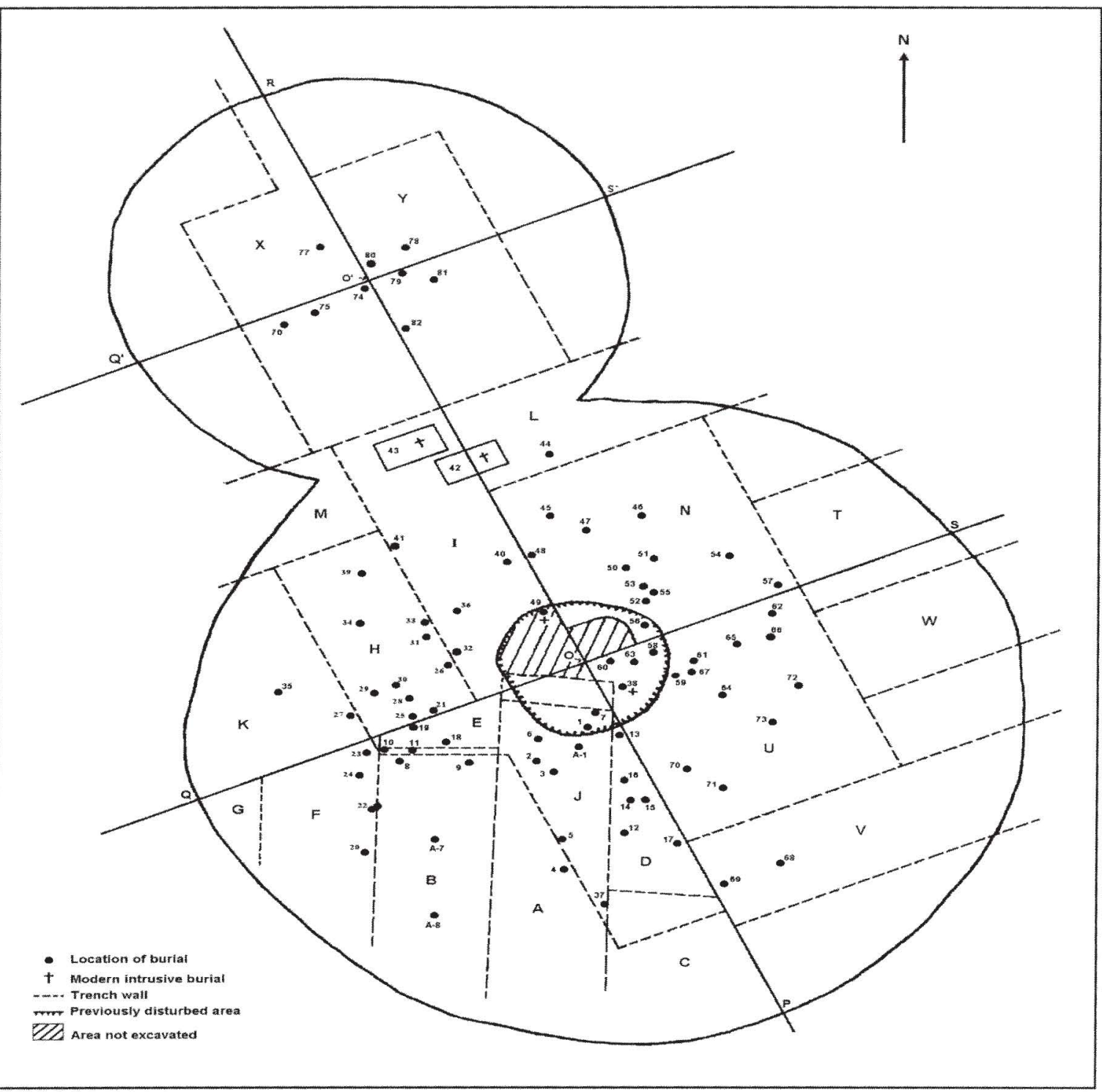

Figure 34. Horizontal distribution of burials in Mound 11, Norman site (34WG2); adapted from Finkelstein (1934b).

12 foot sections. A three foot wide test trench from the center of the mound northward to the edge of the mound was then extended. The eastern half of the mound was dug using a 20 foot trench, with the remaining deposits removed by three lateral trenches extending to the edge of the mound. The trenches were excavated in a stepwise fashion, using levels 18 inches deep (treads) and 36 inches wide.

At first, profiles were taken at nine foot intervals. When no apparent strata were 
noted, these were drawn of only the major axes through the mounds (Figure 33). Some loading, with red and yellow clay and hard lenses of grey, ashy dirt, was noted in the generally homogeneous gravelly fill (Finkelstein and Bell 1950: 11). Feature depths, including those of the burials, were measured from the surface of the mound because a surveying instrument was not available. Profiles were measured from the gravel floor until a Brunton compass was obtained late in the excavation. The horizontal distribution of the burials was also mapped (Figure 34).

After analysis done in 1949, Finkelstein proposed a cultural stratification constructed from laboratory data (Finkelstein and Bell 1950:11-13). The burials from Mound IIa were presumed to be deposited on a surface representing a mound building phase, and "profiles" were projected from their placement. These "profiles" suggested periodic building, with three definite phases and possibly four others for Mound IIa. Three burials, including a cremation in a jar, were placed on the original ground surface. This surface was three to eight inches in depth and contained "much river gravel". Below this topsoil was a six inch layer of gravel with red clay below it. Over these was constructed a mound about 45 feet in diameter and 1.5 feet high. About 15 burials were placed on the surface of the primary mound (always remember that a large pothunter's pit removed the central part of the mound). A second phase added three feet to the height and increased the diameter to 53 feet. Three burials were found within the fill of this second phase. Nine additional burials occurred about 0.5 foot above this for a third phase. The next stage (fourth) raised the height of the mound about four feet with the diameter extended to 60 feet. On the surface of this stage, fourteen burials were placed. Above this height, the burials were scattered and few in number. There could have been two additional episodes of construction, the fifth and sixth. There was a final building phase which resulted in the mound cap. The field notes contained little information about the types of fill in the various stages (Finkelstein and Bell 1950:13). Some burials were found in a compact yellowish dirt, some in a compact black dirt, and some in a compact light grey deposit. Thus, there was either some color symbolism being expressed, or different soils merely came from deposits which were handy to use at the time.

In Mound IIb, there were two or three phases of construction (Finkelstein and Bell 1950:87). An initial burial was made in a shallow, prepared basin (Finkelstein and Bell 1950:14-15). A mound stage about one foot high and 18 feet in diameter was placed above this. On the surface of this first stage were deposited probably five burials. Above this, about midway between the first surface and the top of the mound, were two additional burials, so there may have been three building phases.

From the artifacts associated with the burials in Mound II, no time differences could be seen in the sequence of building the two lobes of the mound. Most of the burials were fragmentary, and the remains were each confined to an area about one foot in diameter, suggesting bundle burials 
(Finkelstein and Bell 1950:15-16). Ear spools found with the burials were stacked or lying side by side. Some of the burials may have been in small, prepared basins about two feet in diameter and six inches de e p (Finkelstein and Bell 1950:16). Some basins showed evidence of burning and cremation.

Four burials, one of them double, found in Mound IIa contained numerous items of burial goods (Finkelstein and Bell 1950:18-20). These are burial 51 from phase 3 , which lay on a bed of bark four feet east-west by two feet north-south (Figure 34a); burial 36 from phase 4 , which was in an indistinct basin (Figure 34b); burial 21 from phase 1 , which was in a basin (Figure 34c); and burial 40/48, also from phase 1 (Figure 34d).

Both lobes of this mound were completely excavated during the WPA Finkelstein. work. Burial record forms would give additional information, but were not

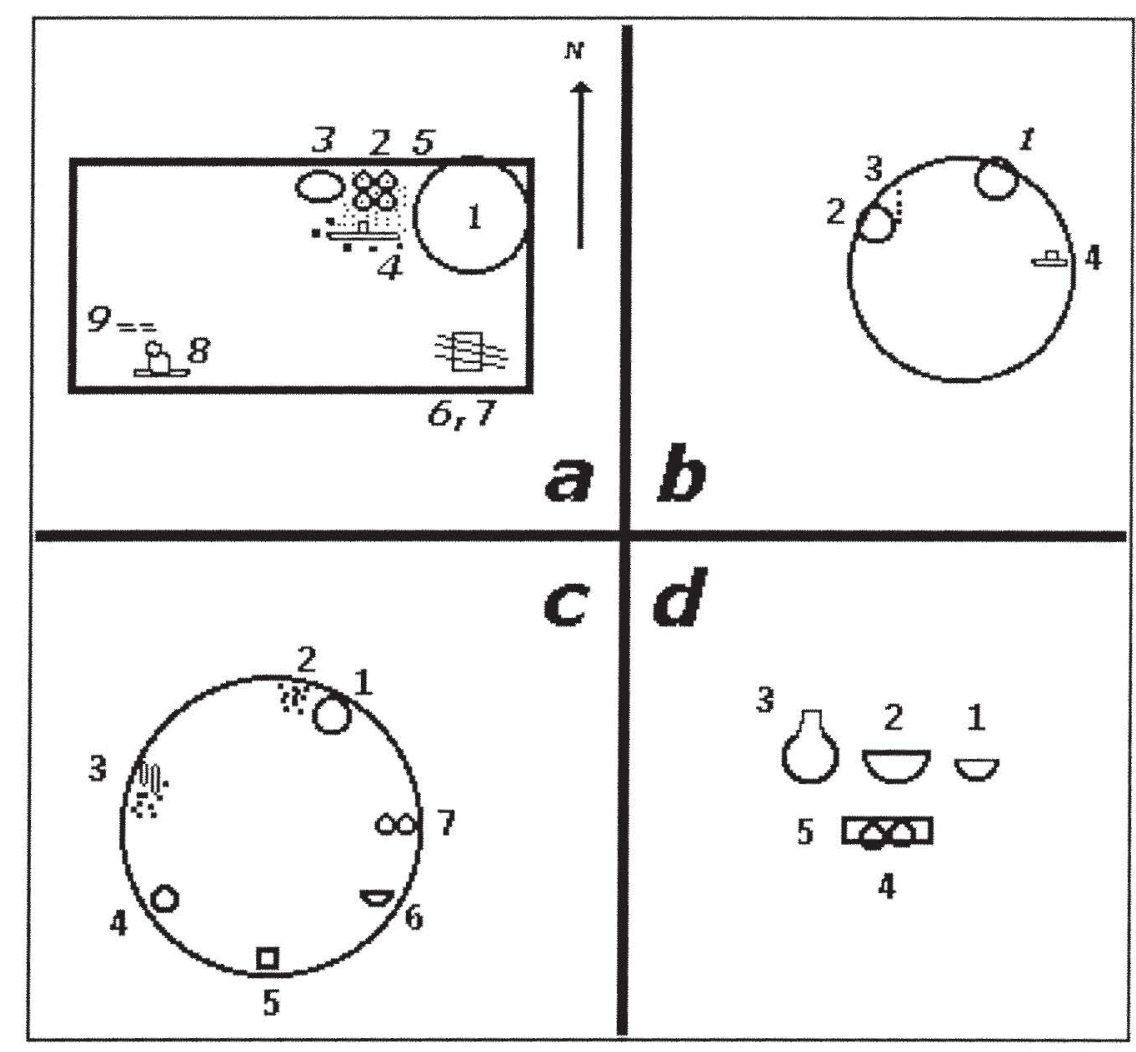

Figure 34. Burials with burial goods from Mound IIa, Norman site (34WG2). a - burial 51 (1 - two green clay discs, one foot diameter, one inch thick; 2 - two sets earspools; 3 - wad of red paint; 4 -large stone doublestemmed pipe, fragments of three small clay double-stemmed pipes, aligned east-west; $5-25+$ pearl beads scattered between ear spools and pipes; 6 - about 80 small projectile points all pointing in the same direction; 7 - bundle of eight solid copper and copper plated wooden bodkins aligned southeast-northwest; 8 - highly eroded limestone effigy pipe; 9 - at least eight long copper plated wooden beads; cane basketry and cloth fragments were seen around some of the objects); $\boldsymbol{b}$ - burial 36 (1 - heap of sherds; 2 - heap of sherds; 3 - nine small points in a northsouth line; 4 - large stone double-stemmed pipe); $\mathrm{c}$ - burial 21 ( 1 flattened wad of green clay about four inches diameter; 2-226 small points; 3 - group of knives and points; 4 - green clay disc, one foot diameter, one inch thick; 5 -fluted barrel-shaped green clay object; 6 round bottomed basin (bowl?); 7 - set of plain ear spools); $d$ - burial 40/48 (1 - pottery cup; 2 - shattered pottery basin; 3 - pottery bottle; 4 set of ear spools; 5 -small copper bird effigy plate); reconstructed from Finkelstein and Bell 1950:18-20; artifacts descriptions as given by 
studied as part of this descriptive project. Because the WPA program was conceived to create work during the Depression, no funds were available to study the items recovered. No comprehensive analysis or description of the burials and their associated goods has ever been published, although a report was written in 1934 as well as a summary report, probably in 1940, by Finkelstein.

\section{MOUND III}

About 745 feet east of Mound I lay Mound III, a single lobed unit (Finkelstein, Figure A, page 8, this volume). The terrace edge dropped away sharply about 325 feet east of the mound (Finkelstein and Bell 1950:8). In the 1930s, it had a diameter of 140 feet and a height of six feet. After being plowed for years, the mound had assumed a domed shape. Because the ground south and west of the mound dipped slightly, the mound appeared higher when seen from the west than it did from the east (Finkelstein and Bell 1950:90).

The excavations into this mound were begun in December 1935 and continued until June 1936 under Joe (Bauxar) Finkelstein's supervision (Finkelstein and Bell 1950:4). The excavations were funded through the Works Progress Administration (WPA). After Finkelstein was transferred to Spiro, the work was continued by Herbert Antle until July.

The work began by sinking four test pits just outside the mound periphery on each of the major axes (Figure 35; Finkelstein and Bell 1950:90). The pits were underlain by gravel; all contained some cultural debris in a dark topsoil. The depth to which this debris extended varied (A - 18 inches; B - 16.5 inches; C - 12 inches; D 2 inches).

After completion of the test pits, larger exploratory trenches were carried into the mound (Finkelstein and Bell 1950:90). At the western edge, a 20 foot wide trench was dug 10 feet into the mound. The deposits contained a small amount of cultural debris, but no features were found. A trench 60 feet wide (north-south) was excavated on the eastern edge of the mound. Postholes were seen at the southern end of the trench. The trench on the southern edge of the mound contained burials almost immediately. The burial pits could be traced to the mound surface; thus, the burials were considered intrusive and termed the Searcy Compex by Finkelstein (Finkelstein and Bell 1950: 91). A preliminary report was written by Finkelstein, probably in 1940, describing the "Searcy Complex". However, because the burials and their associated artifacts were not restudied for this paper, the information contained in it has not been included. Although the cultural material within the mound fill was sparse, some was present. Most common was charcoal, but sherds, a small ceramic male figure, a few points and bifaces, a pipe fragment, a celt, broken metates, hammerstones, bone 
awls, an incised bone ring, a terrapin carapace rattle, and a bison-horn spoon were recorded.

After the exploratory trenches were finished, 10 foot wide trenches were dug into the mound on the north side of the "east-west" axis. Both trenches were continued 30 feet toward the mound center. No features were found in the trench excavated from the east. However, postholes were exposed in the trench from the west. These postholes were first seen at about three feet above the gravel. No

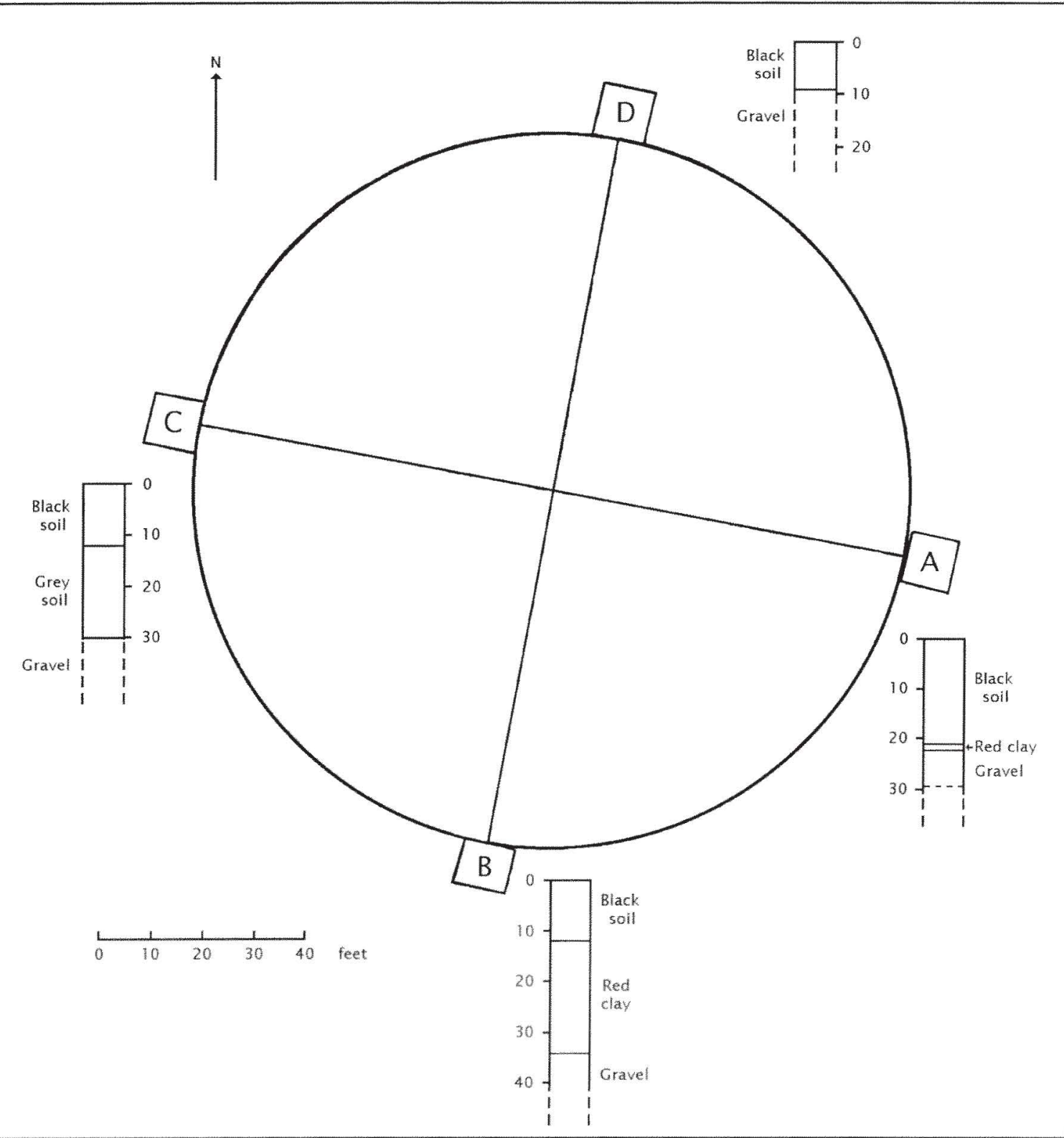

Figure 35. Location of initial test squares and "profiles" of the soils, Mound III, Norman site (34WG2); constructed from Finkelstein and Bell 1950:90. 


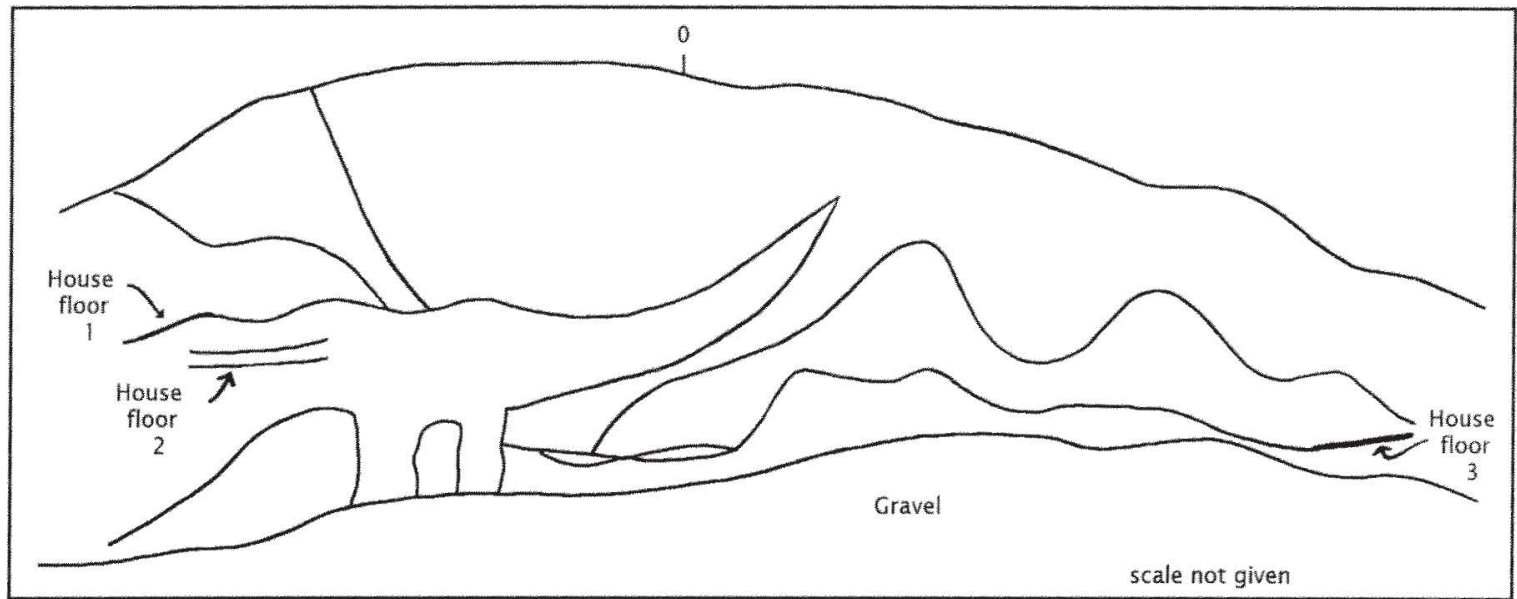

Figure 36. Profile \#2, Mound III, Norman site (34WG2); adapted from sketch probably from Finkelstein's 1936 field notes.

prepared floor or mound surface was observed in correlation with these.

The posthole patterns from the southern end of the exploratory trench on the eastern side of the mound were followed further into the mound, exposing three "house" floors (Profile \#2, Figure 36;

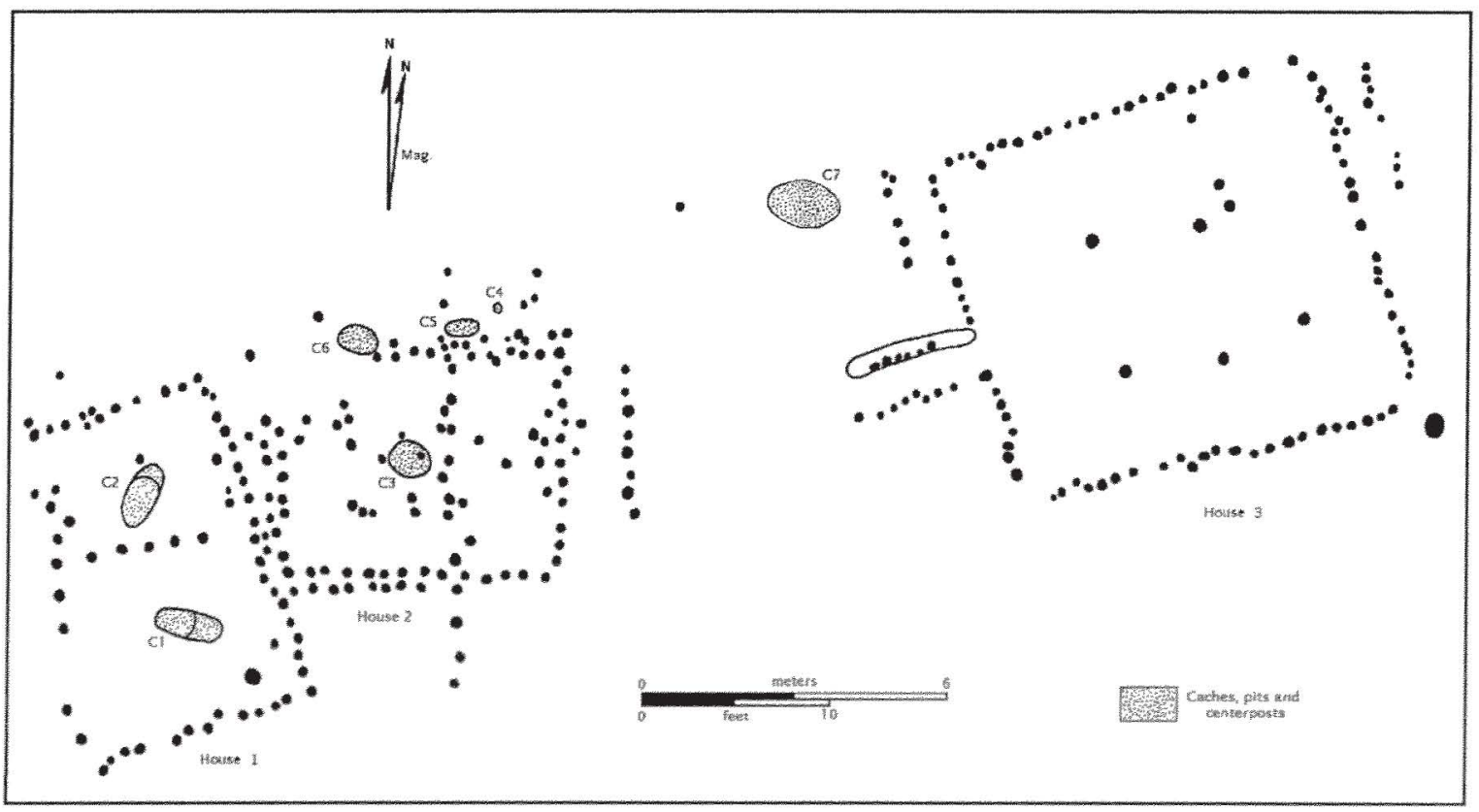

Figure 37. House patterns from Mound III, Norman site (34WG2); House 3 is not shown at the actual distance from the House 1 and 2 complex; adapted from sketch by Finkelstein, probably 1936. 
"house" floors (Profile \#2, Figure 36; Finkelstein 1934/5:10-11). House floor 3 (H3) measured 24 feet east-west and 21 feet north-south, with rounded corners (Figure 37). An extended entryway was present at the center of the west wall. The structure had four center posts which formed a rectangle six feet east-west and eight feet north-south. On the floor were fragments of "charred posts and wattle", but no daub was recognized. No hearth or pits were found. Outside the house, 1.5 feet to the north, was a small gravel ridge, into which at one foot intervals were set posts slanting toward the house.

West of $\mathrm{H} 3$ and on a slightly higher surface were two more structures (Figure 36). One of these structures was about two inches lower, and therefore apparently earlier, than the other. This older "house" was approximately 16 feet square. The upper "house" was rectangular and meas- ured 20 by 11 feet. Finkelstein (Finkelstein and Bell 1950:11) states that it had two rooms. This assessment may be analogous to the initial view of House Unit IV under Mound Ib, and probably represents overlapping structures. Neither of these "houses" had discrete center posts, a prepared hearth, or extended entryway, although these could have been obscured or destroyed if indeed there were overlapping structures. According to Finkelstein (1934/5:11), "each room of the two structures contained a deep central floor cache". Again, this identification may be similar to that at House Unit IV, Mound Ib, where the central "caches" were actually features used to raise and hold the center posts.

About half of this mound was excavated during the WPA work. The remainder was used as fill during causeway construction.

\section{SITE UNIT IVc}

North of Mound II, east of Mound III, and south of Mound VI, was what Finkelstein (1932) described as a "flake bed" (Finkelstein, Figure A, page 8, this volume). In addition to flakes, some bones (species unknown) were recovered. No further work was done in the area before it was destroyed.

\section{MOUND V}

This mound was only 1.5 feet high and had a diameter of about 50 feet. It was about 325 feet south of Mound Ia (Finkelstein, Figure A, page 8 , this volume). The wall profile of a small test pit placed in the mound during the 1948 excavations show- ed "loading". Thus, this mound was probably constructed as part of the ceremonial center instead of being a natural feature. It was destroyed during reservoir/causeway construction, so that no further information could be gathered during later work. 


\section{MOUND VI}

This dome-shaped mound was 45 feet in diameter and 1.5 feet high. It was located about 200 feet north and slightly east of Mound III (Finkelstein, Figure A, page 8, this volume). Because no testing was done at this mound, it is impossible to say whether it was of cultural or natural origin. It was also destroyed during the construction of the causeway.

\section{MOUND VII}

Mound VII was described as domeshaped, 45 feet in diameter, and 2.5 feet high. It was located 210 feet south of Mound IIa (Finkelstein, Figure A, page 8, this volume). It was tested in 1936; the notes state that there were no positive results. This may mean that this was a natural feature or that any construction stages present were not recognized at the time of testing. The mound was destroyed during causeway construction.

\section{THE EXTRA-MOUND AREAS}

A sparse scatter of refuse, including knapping debris, extended about 1000 feet northeastward from Mound Ia (Site Unit IVa; Finkelstein, Figure A, page 8, this volume). Knapping debris was also noted on the terrace edge east of Mound III. The large intra-mound area between Mounds I and III was almost devoid of cultural material, as was the area west of Mound I.
However, little, if any, excavation was done in these areas except immediately adjacent to the mounds. It is possible that the area between the mounds could have been a plaza similar to the one at the Spiro site (Rogers, Moore, and Greaves 1982). However, because it was destroyed before any excavation could be carried out, this will never be known.

\section{COMMENTS}

Because of the nature of the fieldwork conditions during the CWA and WPA era, documentation of the excavations carried out during this time was frequently quite incomplete. Archeologists often were responsible for supervising crews at several far-flung sites (Alice Marriott, personal communication). This left them little time to undertake writing of meticulous or voluminous field notes. The workers were untrained, and scientific field techniques were still being refined in 
the fledgling field of archeology. Apparently, no screening of the fill was done; thus, any small artifacts were probably lost, except for those noted during the excavation.

As studies are done on the materials recovered, our perception of the stratigraphy of the mounds may well change. It will certainly undergo a considerable change when new profiles of the remnant of Mound I are done and become available. There is much which will never be known because of the destruction of the site by causeway construction and by the erosion of the remnant of Mound I in the $50+$ years since Caldwell's work at the site.

\section{BIBLIOGRAPHY}

Bell, Robert E.

1948a Field notes and maps from July 2 August 25, WgNr - Norman site. Curated at Sam Noble Oklahoma Museum of Natural History, The University of Oklahoma, Norman.

1948b Norman site report. Unpublished ms. on file at Sam Noble Oklahoma Museum of Natural History, The University of Oklahoma, Norman.

\section{Caldwell, Joseph}

1948a Field notes, maps, and photos from August 21 - September 15. Curated at Sam Noble Oklahoma Museum of Natural History, The University of Oklahoma, Norman.

1948b Norman Site, Fort Gibson Reservoir, Wagoner County, Oklahoma. Unpublished ms. on file at the Sam Noble Oklahoma Museum of Natural History, The University of Oklahoma, Norman.
Finkelstein, J. Joe

1932 Field notes and maps for the "Wagoner Mound Sites". Curated at the Sam Noble Oklahoma Museum of Natural History, The University of Oklahoma, Norman.

1934 Field notes and maps for Mound $\mathrm{Ib}$ and House IVa. Curated at the Sam Noble Oklahoma Museum of Natural History, The University of Oklahoma, Norman.

1934b Report on Excavation in Mounds of the Mound-Builder Culture near Wagoner, Oklahoma. Report \#1: Excavation in Burial Mound - Unit II. Unpublished ms. on file at the Sam Noble Oklahoma Museum of Natural History, The University of Oklahoma, Norman.

1934/5 Excavations of House Sites and Mound I2. Unpublished ms. on file at the Sam Noble Oklahoma Museum of Natural History, The University of 
Oklahoma, Norman.

1940a Excavations on the Norman Site near Wagoner, Oklahoma. Unpublished ms. on file at the Sam Noble Oklahoma Museum of Natural History, The University of Oklahoma, Norman.

1940b The Norman Site Excavations Near Wagoner, Oklahoma. The Oklahoma Prehistorian 3(3):2-15.

Finkelstein, J. Joe, and Robert E. Bell 1950 The Norman Site, WgNr, Wagoner County, Oklahoma. Unpublished ms. on file at the Sam Noble Oklahoma Museum of Natural History, The University of Oklahoma, Norman.
Kay, Marvin, George Sabo III, and Ralph Merletti

1989 Late Prehistoric Settlement Patterning: A View from Three Caddoan Civic-Ceremonial Centers in Northwest Arkansas. In: Contributions to Spiro Archeology: Mound Excavations and Regional Perspectives, ed. by J. Daniel Rogers, Don G. Wyckoff, and Dennis A. Peterson, pp. 129 - 157. Oklahoma Archeological Survey, Studies in Oklahoma's Past 16. Norman.

Rogers, J. Daniel, Michael C. Moore, and Rusty Greaves

1982 Spiro Archaeology: The Plaza. Oklahoma Archeological Survey, Studies in Oklahoma's Past 10. Norman. 